\title{
Review
}

\section{The Role of Cytokines in the Pathogenesis of Schizophrenia}

\author{
Bartosz Dawidowski ${ }^{1}\left(\mathbb{D}\right.$, Adrianna Górniak ${ }^{1}$, Piotr Podwalski ${ }^{1, *}$,, Zofia Lebiecka ${ }^{2}$, Błażej Misiak ${ }^{3}(\mathbb{C}$ \\ and Jerzy Samochowiec ${ }^{1}$ D \\ 1 Department of Psychiatry, Pomeranian Medical University, 71-460 Szczecin, Poland; \\ aravial.mg@gmail.com (B.D.); adrianna.gorniak@vp.pl (A.G.); samoj@pum.edu.pl (J.S.) \\ 2 Department of Health Psychology, Pomeranian Medical University, 71-210 Szczecin, Poland; \\ zofia.lebiecka@gmail.com \\ 3 Department of Psychiatry, Division of Consultation Psychiatry and Neuroscience, Medical University, \\ 50-367 Wroclaw, Poland; blazej.misiak@umed.wroc.pl \\ * Correspondence: piotr.podwalski@pum.edu.pl; Tel.: +48-510-091-466
}

Citation: Dawidowski, B.; Górniak, A.; Podwalski, P.; Lebiecka, Z.;

Misiak, B.; Samochowiec, J. The Role of Cytokines in the Pathogenesis of Schizophrenia. J. Clin. Med. 2021, 10, 3849. https://doi.org/10.3390/ jcm10173849

Academic Editor: Napoleon Waszkiewicz

Received: 4 August 2021

Accepted: 24 August 2021

Published: 27 August 2021

Publisher's Note: MDPI stays neutral with regard to jurisdictional claims in published maps and institutional affiliations.

Copyright: (c) 2021 by the authors. Licensee MDPI, Basel, Switzerland. This article is an open access article distributed under the terms and conditions of the Creative Commons Attribution (CC BY) license (https:/ / creativecommons.org/licenses/by/ $4.0 /)$.

\begin{abstract}
Schizophrenia is a chronic mental illness of unknown etiology. A growing and compelling body of evidence implicates immunologic dysfunction as the key element in its pathomechanism. Cytokines, whose altered levels have been increasingly reported in various patient populations, are the major mediators involved in the coordination of the immune system. The available literature reports both elevated levels of proinflammatory as well as reduced levels of anti-inflammatory cytokines, and their effects on clinical status and neuroimaging changes. There is evidence of at least a partial genetic basis for the association between cytokine alterations and schizophrenia. Two other factors implicated in its development include early childhood trauma and disturbances in the gut microbiome. Moreover, its various subtypes, characterized by individual symptom severity and course, such as deficit schizophrenia, seem to differ in terms of changes in peripheral cytokine levels. While the use of a systematic review methodology could be difficult due to the breadth and diversity of the issues covered in this review, the applied narrative approach allows for a more holistic presentation. The aim of this narrative review was to present up-to-date evidence on cytokine dysregulation in schizophrenia, its effect on the psychopathological presentation, and links with antipsychotic medication. We also attempted to summarize its postulated underpinnings, including early childhood trauma and gut microbiome disturbances, and propose trait and state markers of schizophrenia.
\end{abstract}

Keywords: schizophrenia; cytokines; antipsychotics; psychosis; neuroinflammation

\section{Introduction}

Schizophrenia is a chronic mental disorder with a complex etiopathogenesis, which involves both congenital and environmental factors [1]. It leads to neurodegenerative changes in the central nervous system (CNS) and a significant impairment of social functioning [2-4]. Its lifetime incidence has been estimated at 7.1 per 1000 people, and the male to female risk ratio is 1.4:1 [5]. Alongside other, less pronounced symptoms, schizophrenia involves the presence of positive (e.g., delusions, hallucinations), negative (e.g., anhedonia, social withdrawal), and affective symptoms, as well as cognitive dysfunction (e.g., impaired working memory) [1].

Recent research indicates that subclinical inflammation in the CNS and immune dysregulation may play a role in the etiopathogenesis of schizophrenia, which is supported by immunogenetic evidence and a higher incidence of autoimmune diseases in patients with schizophrenia relative to the general population [6-8]. Neuroinflammation can lead to white matter pathology, dysconnectivity, and thus to the onset of schizophrenia symptoms [8].

Cytokines are signaling proteins that affect mainly immune cells, regulating their proliferation and activation [9]. Produced by a wide variety of cell populations, they 
play a critical role in the coordination of the inflammatory response [9]. Another factor considered important in studies on the etiopathogenesis of schizophrenia are chemokines, i.e., a subgroup of cytokines whose main role is to attract immune cells to the site of inflammation [10]. In addition, both chemokines and non-chemokine cytokines modulate the processes of neurogenesis and neural pruning, and may affect behavior [10,11].

Numerous studies, including many meta-analyses, demonstrate alterations in blood cytokine levels in schizophrenia patients compared to healthy controls (HC) [12-16]. Additionally, they tend to manifest the increased mRNA expression of cytokine genes in lymphocytes relative to HC [17]. This may stem from epigenetic mechanisms underlying the relationship between schizophrenia and stress in early childhood $[18,19]$. A known risk factor for schizophrenia, early childhood trauma is associated with poorer responses to treatment and symptom characteristics [18,20-23]. Elevated peripheral and cerebrospinal fluid (CSF) cytokine levels are hypothesized to partially result from disturbed gut microbiome composition, which were observed in patients with schizophrenia and may be caused by both maternal and developmental stress [24-28].

Schizophrenia research is typically conducted on a small patient population. The most extensively researched cohort is patients with first-episode psychosis (FEP), whose functioning is monitored prior to the initiation of antipsychotic treatment (first episode antipsychotics naive, FEAN). The second group consists of patients showing subsequent psychotic episodes, who receive treatment due to relapse (acute relapsed chronic, ARCh), while the third includes those in remission (stable chronic, SCh). Some other, far less studied patient populations include those with early onset psychosis (EOP) and patients at clinical high risk (CHR) or ultra-high risk (UHR) of psychosis.

The aim of this narrative review is to present the most valuable evidence on cytokine dysregulation in schizophrenia, the links between cytokine levels and psychopathological presentation, as well as their alterations in response to antipsychotics. We will also investigate the possible underpinnings of changes in the cytokine system.

\section{Materials and Methods}

Due to the large variety within existing research, as well as the immense amount of data accumulated over the years, including systematic reviews and meta-analyses, we decided against the use of systematic methodologies and instead resolved to present a narrative review. This strategy, despite certain limitations, enables a more holistic approach to the role of cytokine alterations in the etiopathogenesis of schizophrenia, which may prove particularly useful for clinicians and researchers alike who want to explore this very timely subject.

To this end, a PubMed literature search was conducted to identify all relevant studies and meta-analyses published between January 1st 2010 and April 22th 2021, using either "cytokines and schizophrenia" or "cytokines and antipsychotics" as the search terms, followed by a subsequent one using "schizophrenia childhood trauma" and "schizophrenia microbiome". In addition, we performed a manual search of the references of articles selected for inclusion in this paper. Only full-text articles published in the English language were included.

\section{Cytokines and Schizophrenia}

Presented in Table 1 are the results of meta-analyses concerning alterations in peripheral (serum or plasma) cytokine levels in FEAN and FEP populations, and Table 2 shows those in ARCh, SCh and CHR/UHR populations. Table 3 presents CSF cytokine levels in patients with schizophrenia. Based on the available meta-analytical data, it is hypothesized that there is a certain disturbance in the balance between pro-inflammatory cytokines, such as interleukin-6 (IL-6) or IL- $1 \beta$, and anti-inflammatory cytokines such as interleukin 10 (IL-10) [6,29]. This hypothesis is supported by the protective effect of Th2 cytokines and anti-inflammatory cytokines, whose elevated prenatal levels in the maternal blood may reduce the risk of schizophrenia in the offspring [30,31]. Additionally, a meta- 
analysis by Zhang et al. suggested a particularly large influence of cytokine imbalance on the risk of schizophrenia in the offspring in the early stages of pregnancy [31]. Elevated levels of proinflammatory cytokines may cause the overactivation of astrocytes and microglia, and the presynaptic stimulation of dopaminergic receptors in the midbrain [32]. They are also known to affect kynurenine pathway regulation and disturb glutamatergic transmission [33].

Table 1. Summary of meta-analytical data concerning peripheral cytokine levels in first episode psychosis (FEP) and first episode drug naïve (FEAN) patients as compared to healthy controls.

\begin{tabular}{|c|c|c|c|c|c|c|c|c|c|c|c|c|c|c|}
\hline \multirow{2}{*}{ Marker } & \multicolumn{2}{|c|}{$\begin{array}{l}\text { Miller et al. } \\
\text { (2011) }\end{array}$} & \multicolumn{2}{|c|}{$\begin{array}{l}\text { Upthegrove } \\
\text { et al. (2014) }\end{array}$} & \multicolumn{2}{|c|}{$\begin{array}{l}\text { Goldsmith } \\
\text { et al. (2016) }\end{array}$} & \multicolumn{2}{|c|}{$\begin{array}{l}\text { Fang et al. } \\
\text { (2017) }\end{array}$} & \multicolumn{2}{|c|}{$\begin{array}{l}\text { Frydecka et al. } \\
(2018) *\end{array}$} & \multicolumn{2}{|c|}{$\begin{array}{l}\text { Pillinger et al. } \\
\text { (2019) }\end{array}$} & \multicolumn{2}{|c|}{$\begin{array}{l}\text { Çakici et al. } \\
\text { (2020) }\end{array}$} \\
\hline & Alt. & $\begin{array}{c}\mathrm{nS} \\
(\mathrm{nP})\end{array}$ & Alt. & $\begin{array}{c}\mathrm{nS} \\
(\mathrm{nP})\end{array}$ & Alt. & $\begin{array}{c}\mathrm{nS} \\
(\mathrm{nP})\end{array}$ & Alt. & $\begin{array}{c}\mathrm{nS} \\
(\mathrm{nP})\end{array}$ & Alt. & $\begin{array}{c}\mathrm{nS} \\
(\mathrm{nP})\end{array}$ & Alt. & $\begin{array}{c}\mathrm{nS} \\
(\mathrm{nP})\end{array}$ & Alt. & $\begin{array}{c}\mathrm{nS} \\
(\mathrm{nP})\end{array}$ \\
\hline IL-1 $\beta$ & $\uparrow$ & $\begin{array}{c}3 \\
(151)\end{array}$ & $\uparrow$ & 3 (99) & $\uparrow$ & $\begin{array}{c}6 \\
(333)\end{array}$ & NA & $0(0)$ & NA & $0(0$ & - & $(269)$ & - & $\begin{array}{c}9 \\
(298)\end{array}$ \\
\hline $\begin{array}{l}\text { IL- } \\
\text { 1RA }\end{array}$ & NA & $0(0)$ & NA & $0(0)$ & $\uparrow$ & $\begin{array}{c}2 \\
(194)\end{array}$ & NA & $0(0)$ & NA & $0(0$ & NA & $0(0)$ & NA & $0(0)$ \\
\hline IL-2 & - & $\begin{array}{c}4 \\
(116)\end{array}$ & - & $3(26)$ & - & $\begin{array}{c}5 \\
(140)\end{array}$ & NA & $0(0)$ & NA & $0(0$ & - & (205) & - & $\begin{array}{c}10 \\
(249)\end{array}$ \\
\hline $\begin{array}{l}\text { sIL- } \\
2 R\end{array}$ & $\uparrow$ & $3(30)$ & $\uparrow$ & $3(58)$ & $\uparrow$ & $3(30)$ & NA & $0(0)$ & NA & $0(0$ & NA & (36) & NA & $0(0)$ \\
\hline IL-4 & NA & $0(0)$ & - & $2(93)$ & $\downarrow$ & $\begin{array}{c}4 \\
(193)\end{array}$ & NA & $0(0)$ & NA & $0(0$ & - & (320) & - & $\begin{array}{c}8 \\
(308)\end{array}$ \\
\hline IL-6 & $\uparrow$ & $\begin{array}{c}4 \\
(117)\end{array}$ & $\uparrow$ & $\begin{array}{c}5 \\
(181)\end{array}$ & $\uparrow$ & $\begin{array}{c}11 \\
(506)\end{array}$ & NA & $0(0)$ & NA & $0(0$ & $\uparrow$ & $(652)$ & $\uparrow$ & $\begin{array}{c}14 \\
(540)\end{array}$ \\
\hline IL-8 & NA & $0(0)$ & NA & $0(0)$ & $\uparrow$ & $2(49)$ & NA & $0(0)$ & - & $3(99)$ & - & (96) & $\uparrow$ & $\begin{array}{c}6 \\
(123)\end{array}$ \\
\hline IL-10 & NA & $0(0)$ & NA & $0(0)$ & $\uparrow$ & $\begin{array}{c}4 \\
(357)\end{array}$ & NA & $0(0)$ & NA & $0(0$ & - & $(415)$ & - & $\begin{array}{c}10 \\
(567)\end{array}$ \\
\hline IL-12 & $\uparrow$ & $2(78)$ & NA & $0(0)$ & - & $\begin{array}{c}3 \\
(258)\end{array}$ & NA & $0(0)$ & NA & $0(0$ & NA & $0(0)$ & - & $2(15)$ \\
\hline IL-17 & NA & $0(0)$ & NA & $0(0)$ & - & $\begin{array}{c}2 \\
(157)\end{array}$ & - & $\begin{array}{c}5 \\
(313)\end{array}$ & NA & $0(0$ & $\uparrow$ & $(413)$ & NA & $0(0)$ \\
\hline IL-18 & NA & $0(0)$ & NA & $0(0)$ & - & $\begin{array}{c}3 \\
(335)\end{array}$ & NA & $0(0)$ & NA & $0(0$ & NA & $0(0)$ & NA & $0(0)$ \\
\hline $\begin{array}{c}\text { TNF- } \\
\alpha\end{array}$ & $\uparrow$ & $\begin{array}{c}4 \\
(200)\end{array}$ & $\uparrow$ & $3(99)$ & $\uparrow$ & $\begin{array}{c}9 \\
(587)\end{array}$ & NA & $0(0)$ & NA & $0(0$ & $\uparrow$ & $(488)$ & $\uparrow$ & $\begin{array}{c}11 \\
(376)\end{array}$ \\
\hline $\begin{array}{c}\text { IFN- } \\
\gamma\end{array}$ & $\uparrow$ & $2(48)$ & - & $\begin{array}{c}3 \\
(103)\end{array}$ & $\uparrow$ & $\begin{array}{c}7 \\
(452)\end{array}$ & NA & $0(0)$ & NA & $0(0$ & $\uparrow$ & (344) & - & $\begin{array}{c}11 \\
(334)\end{array}$ \\
\hline $\begin{array}{c}\text { TGF- } \\
\beta\end{array}$ & $\uparrow$ & $2(81)$ & NA & $0(0)$ & $\uparrow$ & $\begin{array}{c}3 \\
(169)\end{array}$ & NA & $0(0)$ & NA & $0(0)$ & $\uparrow$ & (133) & - & $2(98)$ \\
\hline
\end{tabular}

Alt.-alteration, nS—number of studies, nP—number of patients, NA—data not available, — not alternated, $\uparrow$-elevated levels, $\downarrow$-reduced levels. * This metanalysis included non-drug naïve FEP patients. 
Table 2. Summary of meta-analytical data concerning peripheral cytokine levels in acute relapsed chronic (ARCh), stable chronic (SCh) and clinical high-risk or ultra-high-risk (CHR/UHR) patients as compared to healthy controls.

\begin{tabular}{|c|c|c|c|c|c|c|c|c|c|c|c|c|c|c|}
\hline \multirow{2}{*}{ Marker } & \multicolumn{4}{|c|}{ Miller et al. (2011) } & \multicolumn{4}{|c|}{ Goldsmith et al. (2016) } & \multicolumn{2}{|c|}{$\begin{array}{c}\text { Frydecka et al. } \\
\text { (2018) }\end{array}$} & \multicolumn{2}{|c|}{$\begin{array}{l}\text { Park et al. } \\
\text { (2019) }\end{array}$} & \multicolumn{2}{|c|}{$\begin{array}{l}\text { Misiak et al. } \\
\text { (2021) }\end{array}$} \\
\hline & ARCh & $\begin{array}{c}\mathrm{nS} \\
(\mathrm{nP})\end{array}$ & SCh & $\begin{array}{c}\mathrm{nS} \\
(\mathrm{nP})\end{array}$ & ARCh & $\begin{array}{c}\mathrm{nS} \\
(\mathrm{nP})\end{array}$ & $\mathrm{SCh}$ & $\begin{array}{c}\mathrm{nS} \\
(\mathrm{nP})\end{array}$ & $\mathrm{ARCh}$ & $\begin{array}{c}\mathrm{nS} \\
(\mathrm{nP})\end{array}$ & CHR & $\begin{array}{c}\mathrm{nS} \\
(\mathrm{nP})\end{array}$ & $\begin{array}{l}\text { CHR/ } \\
\text { UHR }\end{array}$ & $\begin{array}{c}\mathrm{nS} \\
(\mathrm{nP})\end{array}$ \\
\hline IL-1 $\beta$ & NA & $0(0)$ & - & $\begin{array}{c}3 \\
(127)\end{array}$ & $\uparrow$ & $\begin{array}{c}3 \\
(131)\end{array}$ & $\uparrow$ & $\begin{array}{c}4 \\
(330)\end{array}$ & NA & $0(0)$ & $\downarrow$ & $2(14)$ & - & 3 \\
\hline $\begin{array}{l}\text { IL- } \\
\text { 1RA }\end{array}$ & $\uparrow$ & $2(32)$ & NA & $0(0)$ & $\uparrow$ & $2(32)$ & NA & $0(0)$ & NA & $0(0)$ & NA & $0(0)$ & NA & 0 \\
\hline IL-2 & 一 & $2(43)$ & - & $\begin{array}{c}4 \\
(132)\end{array}$ & - & $2(43)$ & 一 & $\begin{array}{c}6 \\
(193)\end{array}$ & NA & $0(0)$ & NA & $0(0)$ & NA & 0 \\
\hline $\begin{array}{l}\text { sIL- } \\
2 \mathrm{R}\end{array}$ & - & $2(32)$ & - & $3(90)$ & $\uparrow$ & $3(58)$ & $\uparrow$ & $\begin{array}{c}3 \\
(116)\end{array}$ & NA & $0(0)$ & NA & $0(0)$ & NA & 0 \\
\hline IL-4 & NA & $0(0)$ & NA & $0(0)$ & $\downarrow$ & $\begin{array}{c}4 \\
(169)\end{array}$ & - & $2(73)$ & NA & $0(0)$ & - & $2(44)$ & NA & 2 \\
\hline IL-6 & $\uparrow$ & $\begin{array}{c}6 \\
(156)\end{array}$ & - & $\begin{array}{c}5 \\
(164)\end{array}$ & $\uparrow$ & $\begin{array}{c}9 \\
(279)\end{array}$ & $\uparrow$ & $\begin{array}{c}12 \\
(711)\end{array}$ & NA & $0(0)$ & $\uparrow$ & $5(81)$ & $\uparrow$ & 7 \\
\hline IL-8 & $\uparrow$ & $2(46)$ & NA & $0(0)$ & $\uparrow$ & $2(46)$ & NA & $0(0)$ & $\uparrow$ & $\begin{array}{c}12 \\
(696)\end{array}$ & - & $3(47)$ & - & 3 \\
\hline IL-10 & $\downarrow$ & $2(46)$ & NA & $0(0)$ & $\downarrow$ & $2(46)$ & - & $\begin{array}{c}4 \\
(118)\end{array}$ & NA & $0(0)$ & - & $2(15)$ & - & 2 \\
\hline IL-12 & NA & $0(0)$ & - & $\begin{array}{c}3 \\
(104)\end{array}$ & NA & $0(0)$ & NA & $0(0)$ & NA & $0(0)$ & - & $3(47)$ & - & 2 \\
\hline $\begin{array}{c}\text { TNF- } \\
\alpha\end{array}$ & $\uparrow$ & $4(78)$ & - & $\begin{array}{c}3 \\
(171)\end{array}$ & $\uparrow$ & $\begin{array}{c}7 \\
(269)\end{array}$ & $\uparrow$ & $\begin{array}{c}9 \\
(508)\end{array}$ & NA & $0(0)$ & - & $2(44)$ & - & 4 \\
\hline $\begin{array}{c}\text { TNF- } \\
\beta\end{array}$ & NA & $0(0)$ & NA & $0(0)$ & NA & $0(0)$ & NA & $0(0)$ & NA & $0(0)$ & - & $2(15)$ & NA & 0 \\
\hline $\begin{array}{c}\text { IFN- } \\
\gamma\end{array}$ & $\uparrow$ & $2(57)$ & - & $2(62)$ & $\uparrow$ & $\begin{array}{c}4 \\
(162)\end{array}$ & $\downarrow$ & $\begin{array}{c}4 \\
(198)\end{array}$ & NA & $0(0)$ & - & $2(24)$ & - & 5 \\
\hline $\begin{array}{c}\text { TGF- } \\
\beta\end{array}$ & $\uparrow$ & $2(78)$ & - & $\begin{array}{c}2 \\
(119)\end{array}$ & $\uparrow$ & $\begin{array}{c}6 \\
(243)\end{array}$ & NA & $0(0)$ & NA & $0(0)$ & NA & $0(0)$ & NA & 0 \\
\hline
\end{tabular}

nS—number of studies, nP—number of patients, NA—data not available, — — not alternated, $\uparrow$ —elevated levels, $\downarrow$-reduced levels.

Table 3. Summary of meta-analytical data concerning cerebrospinal fluid cytokine levels in schizophrenia patients as compared to healthy controls.

\begin{tabular}{ccccccccc}
\hline \multirow{2}{*}{ Marker } & \multicolumn{2}{c}{ Miller et al. (2011) } & \multicolumn{2}{c}{ Wang et al. (2018) } & \multicolumn{2}{c}{$\begin{array}{c}\text { Gallego et al. } \\
\text { (2018) }\end{array}$} & \multicolumn{2}{c}{$\begin{array}{c}\text { Orlovska-waast } \\
\text { et al. (2019) }\end{array}$} \\
& Alt. & nS (nP) & Alt. & nS (nP) & Alt. & nS (nP) & Alt. & nS (nP) \\
\hline IL-1 $\alpha$ & NA & $0(0)$ & - & $2(70)$ & NA & $0(0)$ & - & $3(72)$ \\
IL-1 $\beta$ & $\downarrow$ & $2(13)$ & $\uparrow$ & $3(57)$ & - & $4(56)$ & - & $2(40)$ \\
IL-2 & - & $4(100)$ & - & $4(114)$ & - & $4(121)$ & - & $3(97)$ \\
sIL-2R & NA & $0(0)$ & $\downarrow$ & $2(19)$ & NA & $0(0)$ & NA & $0(0)$ \\
IL-6 & - & $2(42)$ & $\uparrow$ & $7(244)$ & $\uparrow$ & $8(256)$ & $\uparrow$ & $7(230)$ \\
IL-8 & NA & $0(0)$ & $\uparrow$ & $3(112)$ & $\uparrow$ & $4(105)$ & $\uparrow$ & $3(95)$ \\
IL-12 & - & $2(40)$ & NA & $0(0)$ & NA & $0(0)$ & NA & $0(0)$ \\
\hline
\end{tabular}

Alt.—alteration, $\mathrm{nS}$ - number of studies, $\mathrm{nP}$-number of patients, NA—data not available, — - not alternated, $\uparrow$ —elevated levels, $\downarrow$ 一reduced levels.

A summary of the general effect of antipsychotics on cytokine levels is available in Table 4, while results stratified by population can be found in Table 5 . 
Table 4. Meta-analytical data concerning the effects of antipsychotics on peripheral cytokine levels without stratification by specific treatment or population.

\begin{tabular}{|c|c|c|c|c|c|c|c|c|}
\hline \multirow[t]{2}{*}{ Marker } & \multicolumn{2}{|c|}{ Miller et al. (2011) } & \multicolumn{2}{|c|}{$\begin{array}{c}\text { Tourjman et al. } \\
(2011)\end{array}$} & \multicolumn{2}{|c|}{$\begin{array}{c}\text { Goldsmith et al. } \\
\text { (2016) }\end{array}$} & \multicolumn{2}{|c|}{$\begin{array}{c}\text { Romeo et al. } \\
\text { (2018) }\end{array}$} \\
\hline & Effect & $\mathrm{nS}(\mathrm{nP})$ & Effect & $\mathrm{nS}(\mathrm{nP})$ & Effect & $\mathrm{nS}(\mathrm{nP})$ & Effect & $\mathrm{nS}(\mathrm{nP})$ \\
\hline IL-1 $\beta$ & $\downarrow$ & 3 (127) & $\downarrow$ & 3 (127) & $\downarrow$ & 4 (189) & $\downarrow$ & $7(241)$ \\
\hline IL-1RA & NA & $0(0)$ & - & 5 (113) & NA & $0(0)$ & - & $6(131)$ \\
\hline IL-2 & - & 4 (132) & - & $6(239)$ & - & 4 (132) & - & $10(311)$ \\
\hline sIL-2R & $\uparrow$ & $3(90)$ & $\uparrow$ & 8 (165) & $\uparrow$ & $3(90)$ & $\uparrow$ & $11(263)$ \\
\hline IL-4 & NA & $0(0)$ & - & 2 (119) & $\downarrow$ & 2 (186) & - & 7 (399) \\
\hline IL-6 & $\downarrow$ & $4(164)$ & - & $11(350)$ & $\downarrow$ & $11(500)$ & - & $21(784)$ \\
\hline sIL-6R & NA & $0(0)$ & - & $4(84)$ & NA & $0(0)$ & - & 4 (844) \\
\hline IL-8 & NA & $0(0)$ & NA & $0(0)$ & NA & $0(0)$ & - & $4(144)$ \\
\hline IL-10 & NA & $0(0)$ & - & $2(52)$ & NA & $0(0)$ & - & $8(210)$ \\
\hline IL-12 & $\uparrow$ & $3(104)$ & $\uparrow$ & $2(74)$ & $\uparrow$ & $3(104)$ & - & $4(121)$ \\
\hline IL-17 & NA & $0(0)$ & NA & $0(0)$ & - & 2 (193) & - & $3(248)$ \\
\hline IL-23 & NA & $0(0)$ & NA & $0(0)$ & NA & $0(0)$ & - & $2(68)$ \\
\hline TNF- $\alpha$ & - & $3(171)$ & - & $9(320)$ & - & $6(310)$ & - & 19 (579) \\
\hline $\begin{array}{c}\text { sTNF- } \\
\text { R1 }\end{array}$ & NA & $0(0)$ & NA & $0(0)$ & NA & $0(0)$ & - & $5(91)$ \\
\hline $\begin{array}{c}\text { sTNF- } \\
\text { R2 }\end{array}$ & NA & $0(0)$ & NA & $0(0)$ & NA & $0(0)$ & $\uparrow$ & $3(49)$ \\
\hline IFN- $\gamma$ & - & $2(62)$ & $\downarrow$ & 3 (138) & - & $4(265)$ & $\downarrow$ & $8(380)$ \\
\hline TGF- $\beta$ & $\downarrow$ & 2 (119) & - & $3(156)$ & - & $4(286)$ & - & $5(303)$ \\
\hline
\end{tabular}

$\mathrm{nS} —$ number of studies, $\mathrm{nP}$ —number of patients, — no effect, $\uparrow$ —levels increased after therapy, $\downarrow$-levels decreased after therapy.

Table 5. Meta-analytical data concerning the effect of antipsychotics on peripheral cytokine levels in first episode psychosis (FEP), first episode drug naïve (FEAN), acute relapsed chronic (ARCh), stable chronic (SCh) and clinical high-risk or ultra-high risk (CHR/UHR) patients.

\begin{tabular}{|c|c|c|c|c|c|c|c|c|c|c|c|c|}
\hline \multirow{3}{*}{ Marker } & \multirow{2}{*}{\multicolumn{2}{|c|}{$\begin{array}{c}\text { Capuzzi et al. } \\
\text { (2016) } \\
\text { FEAN }\end{array}$}} & \multicolumn{8}{|c|}{ Romeo et al. (2018) } & \multirow{2}{*}{\multicolumn{2}{|c|}{$\begin{array}{c}\text { Marcinowicz } \\
\text { et al. (2021) } \\
\text { FEP }\end{array}$}} \\
\hline & & & \multicolumn{2}{|c|}{ FEAN } & \multicolumn{2}{|c|}{ ARCh } & \multicolumn{2}{|c|}{ SCh } & \multicolumn{2}{|c|}{ Drug Resistant } & & \\
\hline & Effect & $\begin{array}{c}\mathrm{nS} \\
(\mathrm{nP})\end{array}$ & Effect & $\begin{array}{l}\mathrm{nS} \\
(\mathrm{nP})\end{array}$ & Effect & $\begin{array}{l}\mathrm{nS} \\
(\mathrm{nP})\end{array}$ & Effect & $\begin{array}{l}\mathrm{nS} \\
(\mathrm{nP})\end{array}$ & Effect & $\begin{array}{l}\mathrm{nS} \\
(\mathrm{nP})\end{array}$ & Effect & $\begin{array}{l}\mathrm{nS} \\
(\mathrm{nP})\end{array}$ \\
\hline IL-1 $\beta$ & - & $4(112)$ & $\downarrow$ & $4(179)$ & $\downarrow$ & $6(223)$ & NA & $0(0)$ & NA & $0(0)$ & $\downarrow$ & $7(276)$ \\
\hline $\begin{array}{l}\text { IL- } \\
\text { 1RA }\end{array}$ & NA & $0(0)$ & $\mathrm{NA}$ & $0(0)$ & NA & $0(0)$ & - & $2(41)$ & - & $3(58)$ & NA & $0(0)$ \\
\hline IL-2 & $\downarrow$ & $2(69)$ & - & $2(35)$ & - & $9(279)$ & NA & $0(0)$ & NA & $0(0)$ & - & $4(145)$ \\
\hline sIL-2R & NA & $0(0)$ & NA & $0(0)$ & - & $6(182)$ & NA & $0(0)$ & $\uparrow$ & $2(39)$ & NA & $0(0)$ \\
\hline IL-4 & NA & $0(0)$ & $\downarrow$ & $3(167)$ & - & $6(382)$ & NA & $0(0)$ & NA & $0(0)$ & $\downarrow$ & $4(150)$ \\
\hline IL-6 & $\downarrow$ & $4(253)$ & $\downarrow$ & $5(226)$ & $\downarrow$ & $\begin{array}{c}14 \\
(643)\end{array}$ & 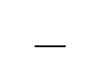 & $2(41)$ & $\uparrow$ & $3(58)$ & $\downarrow$ & $8(409)$ \\
\hline sIL-6R & NA & $0(0)$ & NA & $0(0)$ & $\downarrow$ & $2(53)$ & NA & $0(0)$ & - & $2(31)$ & NA & $0(0)$ \\
\hline IL-8 & NA & $0(0)$ & - & $2(49)$ & NA & $0(0)$ & NA & $0(0)$ & NA & $0(0)$ & NA & $0(0)$ \\
\hline IL-10 & NA & $0(0)$ & - & $3(104)$ & - & $6(173)$ & NA & $0(0)$ & NA & $0(0)$ & $\downarrow$ & $3(150)$ \\
\hline IL-12 & NA & $0(0)$ & NA & $0(0)$ & - & $3(68)$ & NA & $0(0)$ & NA & $0(0)$ & NA & $0(0)$ \\
\hline IL-17 & - & 2 (157) & - & $3(203)$ & - & $3(248)$ & NA & $0(0)$ & NA & $0(0)$ & - & $3(203)$ \\
\hline IL-23 & NA & $0(0)$ & NA & $0(0)$ & NA & $0(0)$ & NA & $0(0)$ & NA & $0(0)$ & NA & $0(0)$ \\
\hline TNF- $\alpha$ & - & $4(214)$ & - & $6(260)$ & $\downarrow$ & $\begin{array}{c}12 \\
(452)\end{array}$ & NA & $0(0)$ & - & $3(51)$ & $\downarrow$ & $7(328)$ \\
\hline $\begin{array}{c}\text { sTNF- } \\
\text { R1 }\end{array}$ & NA & $0(0)$ & NA & $0(0)$ & NA & $0(0)$ & NA & $0(0)$ & $\uparrow$ & $2(39)$ & NA & $0(0)$ \\
\hline $\begin{array}{c}\text { sTNF- } \\
\text { R2 }\end{array}$ & NA & $0(0)$ & NA & $0(0)$ & NA & $0(0)$ & NA & $0(0)$ & $\uparrow$ & $2(39)$ & NA & $0(0)$ \\
\hline IFN- $\gamma$ & - & 2 (157) & - & $3(172)$ & $\downarrow$ & $7(363)$ & NA & $0(0)$ & NA & $0(0)$ & $\downarrow$ & $5(243)$ \\
\hline TGF- $\beta$ & NA & $0(0)$ & NA & $0(0)$ & - & $4(286)$ & NA & $0(0)$ & NA & $0(0)$ & NA & $0(0)$ \\
\hline
\end{tabular}




\subsection{Interleukin-1 $\beta$}

Considered one of the main pro-inflammatory cytokines, interleukin-1 $\beta$ (IL-1 $\beta$ ) is secreted primarily by monocytes, macrophages, microglia and lymphocytes in response to lipopolysaccharide (LPS), other cytokines and complement fragments [34,35]. It is known to activate the expression of numerous genes, including cytokine genes, and increase the secretion of adrenocorticotropin (ACTH) [34], while changes in its levels are reported to disturb neuronal migration [36].

In the case of FEAN patients, meta-analytical data seem to yield somewhat inconsistent results with regard to the peripheral levels of IL- $1 \beta$ as compared to HC, with three metaanalyses by Miller et al., Upthegrove et al. and Goldsmith et al. indicating its increased levels in this patient population [12-14], and two more recent ones by Pillinger et al. and Çakici et al. failing to replicate these results [16,37]. In ARCh patients, there are reports of elevated peripheral levels of IL-1 $\beta$ compared to HC [14], while in the SCh population, they seem to be increased [14] or unaltered [12]. There is evidence of reduced IL-1 $\beta$ levels in the CHR population as compared to HC [38], but a more recent meta-analysis by Misiak et al., including a larger sample of CHR and UHR patients, did not confirm such findings [39]. As regards chronic EOP patients, no significant differences in IL-1 $\beta$ levels were found compared to HC [40]. The results of meta-analyses concerning IL-1 $\beta$ CSF levels are also vastly inconclusive, showing their decreased [12], increased [41] or unaltered [42,43] values compared to $\mathrm{HC}$, although some observations are based on rather small research samples [12].

Interleukin-1 receptor antagonist (IL-1RA) peripheral levels also appear to be elevated in both FEAN [14] and ARCh populations [12,14]. Since IL-1RA is known to reduce the pro-inflammatory effect of IL- $1 \beta$, its higher levels may result from elevated IL-1 $\beta$ levels $[12,14,44]$.

IL-1 $\beta$ peripheral levels correlate with positive and negative symptom severity and the overall psychopathological presentation [45-47]. A correlation has also been demonstrated between elevated IL-1RA levels and cognitive deficits [45].

Where no stratification of patients is applied, either by population or by specific medications used, antipsychotics are reported to reduce IL-1 $\beta$ levels in the blood $[12,14,48,49]$. However, one meta-analysis by Capuzzi et al. showed unaltered levels of IL- $1 \beta$ in the blood of FEAN patients in response to antipsychotics [50], while another by Romeo et al., based on a larger sample, showed its decreased levels [48]. The latter effect of antipsychotics was also reported in FEP patients [51]. Antipsychotics seem to also reduce IL-1 $\beta$ peripheral levels in the ARCh population [48]. When stratifying by specific antipsychotics, decreased IL-1 $\beta$ peripheral levels were reported in response to treatment with risperidone [48].

\subsection{Interleukin-2}

IL-2 is produced upon the stimulation of CD28, mainly by T-helper type 1 (Th1) and cytotoxic $\mathrm{T}(\mathrm{Tc})$ lymphocytes. Its anti-inflammatory effect follows the initial proinflammatory action. What is more, IL-2 induces the secretion of IL-6, interferon $\gamma$ (IFN- $\gamma$ ) and other inflammatory mediators [34].

There is no evidence of altered IL-2 peripheral or CSF levels in any patient population, or differences between ARCh and SCh patients versus HC [12,14,16,42,43]. In turn, the levels of soluble IL-2 receptor (sIL-2R), which reduces the biological activity of IL-2 by binding it and thus preventing its anti-inflammatory effect, are elevated in the FEAN group compared to HC [12-14]. As regards the ARCh population, there are reports of it being either unchanged, in a meta-analysis by Miller et al. [12];; or elevated, in a meta-analysis by Goldsmith et al. [14],; but what is worth noting is that in the former work, the authors considered a much smaller sample. Similar results are observed in SCh patients, although in this case the differences in the size of the research samples were less pronounced [12,14]. Interestingly, there is evidence of reduced levels of sIL-2R in the cerebrospinal fluid compared to HC [41]. 
A negative correlation was found between peripheral IL-2 levels, negative symptom severity and cognitive deficits [45]. In addition, patients with elevated levels tended to improve more slowly in response to treatment [45]. What is more, there is a positive correlation between sIL-2R levels and the overall psychopathological presentation $[46,47]$.

Where stratification by patient population or specific medications used was not applied, no links between antipsychotics administration and peripheral IL-2 levels were observed $[12,14,48-50]$. A meta-analysis by Romeo et al. showed unaltered levels of IL-2 in the blood of FEAN patients in response to antipsychotics [48], while another by Capuzzi et al., which included a larger sample, showed reduced levels [50]. However, a metaanalysis of IL-2 levels in FEP patients by Marcinowicz et al. based on the largest sample showed no antipsychotic effect [51]. There is no proven effect of antipsychotics on IL-2 levels in the blood of the ARCh population [48]. Stratification by administered pharmacotherapy found reduced IL-2 levels in response to risperidone, olanzapine and haloperidol, but not to quetiapine [48]. However, such an effect may be temporary [45]. There are consistent reports of elevated peripheral levels of sIL-2R in patients with schizophrenia treated with antipsychotics where no stratification is applied [12,14,48,49], although such an effect has not been observed in AChR patients [48]. Interestingly, elevated levels of sIL-2R were found in response to antipsychotics in both drug-resistant patients and those treated with clozapine, which is the key drug used in this population [48].

\subsection{Interleukin-4}

A pro-inflammatory cytokine, IL-4, is produced by activated Th lymphocytes (mainly Th2 helper lymphocytes), NKT (natural killer T-cell) lymphocytes, mast cells and basophils. Among others, its role is to promote the differentiation of Th into Th2 lymphocytes, and it also increases their cytotoxicity [34]. It is particularly important that it is also known to affect macrophages and microglial cells, and may have a neuroprotective effect by reducing their ability to induce oxidative stress [40]. In addition, it also plays a role in cognitive processes [11].

Although Goldsmith et al. showed reduced levels of IL-4 in FEAN patients [14], three other meta-analyses, including two based on much larger samples, showed its unaltered levels compared to HCs $[13,16,37]$. In addition, Goldsmith et al. indicated decreased IL-4 peripheral levels in ARCh compared to HCs, and theirs was the only meta-analysis of IL-4 blood levels in this patient population [14]. No alterations of IL-4 levels were found in the blood of Sch [14] or CHR populations [38]. In addition, decreased IL-4 levels were observed in the chronic EOP population compared to adult $\mathrm{AChR}$ and $\mathrm{HC}$, which may indicate that reduced peripheral levels of IL-4 are typical only of AChR patients with early-onset psychosis and comorbid minor neurological disorders [40].

A positive correlation was found between IL-4 peripheral concentration and negative symptom severity, as well as the incidence of depressive symptoms [45].

Although one meta-analysis by Goldsmith et al. showed reduced peripheral levels of IL-4 in response to antipsychotics without stratification by patient population or specific medications [14], two others by Romeo et al. and Tourjman et al. did not confirm such an effect of pharmacotherapy [48,49]. In contrast, Romeo et al. showed decreased peripheral levels of IL-4 in FEAN patients treated with antipsychotics, but not in the ARCh population [48]. Such an effect of antipsychotics in FEP patients is also confirmed by the meta-analysis by Marcinowicz et al. [51]. Stratification by applied pharmacotherapy provides evidence of reduced peripheral IL-4 levels after treatment with risperidone, but not with olanzapine, aripiprazole or clozapine [48].

\subsection{Interleukin-6}

IL-6 is another major pro-inflammatory cytokine produced by macrophages, monocytes, and microglia. Its secretion is induced by IL- $1 \beta$, interferons, tumor necrosis factor- $\alpha$ (TNF- $\alpha$ ), lipopolysaccharide, and viral infections [34]. IL-6 increases the synthesis of acutephase proteins, including $\mathrm{C}$-reactive protein (CRP), which may affect the permeability of 
the BBB and the proliferation of microglia [34,38]. Changes in IL-6 levels may disrupt neurogenesis and reduce glutamate reuptake [30]. Soluble IL-6 receptor (sIL-6R) may bind to this cytokine, further increasing its biological activity [14].

IL-6 is one of the most extensively investigated cytokines in schizophrenia research, and with the exception of the meta-analysis by Miller et al., which reported its unaltered levels in SCh patients [12], there are consistent reports of elevated peripheral and CSF levels compared to HC in all patient populations [13,14,41-43], including chronic EOP, $\mathrm{CHR}$ and UHR patients [38-40]. Additionally, evidence suggests a significantly reduced variability in its levels compared to HC, which may indicate that elevated levels of IL-6 is a key element of the schizophrenia immunophenotype [37].

There is a positive correlation between the concentration of IL-6 in the blood and negative and positive symptoms, as well as the overall psychopathological presentation and cognitive deficits [45-47]. Interestingly, the meta-analysis by Miller et al. also showed a negative correlation of IL-6 CSF levels with schizophrenia symptom severity [12].

Two meta-analyses by Miller et al. and Goldsmith et al. showed reduced peripheral levels of IL-6 in response to antipsychotics without stratification by specific medications or patient populations $[12,14]$, but two others by Romeo et al. and Tourjman et al. showed its unaltered levels $[48,49]$. Considering only FEAN patients, metanalyses by Capuzzi et al. and Romeo et al. consistently show reduced IL-6 peripheral levels in response to antipsychotics $[48,50]$. Similar findings have been reported by Marcinowicz et al., including in FEP patients [51]. The effects of antipsychotics in the ARCh population seem to be similar, unlike in SCh patients, whose IL-6 peripheral levels seem to remain unaffected by antipsychotic treatment [48]. Conversely, IL-6 peripheral levels in treatment-resistant patients increase instead of decreasing [48]. Reduced IL-6 levels are observed only in the case of treatment with risperidone, but not olanzapine, quetiapine, aripiprazole, clozapine or haloperidol [48,52]. Interestingly, IL-6 peripheral levels also appear to increase with the duration of the disease [45]. Treatment with antipsychotics leads to reduced peripheral levels of sIL-6R in the ARCh population, but not in FEAN or drug-resistant patients [48].

\subsection{Interleukin-8}

Secreted primarily in response to an antigen by macrophage, T-lymphocytes, neutrophils and other cells, IL-8 is also the most potent chemokine in humans [34]. This pro-inflammatory cytokine intensifies the migration of neutrophils, $\mathrm{T}$ lymphocytes and monocytes, whose enzymes produce oxygen-free radicals and thus increase oxidative stress, which may result in a loss of neurons [12,34].

Research on IL-8 in pregnant women suggests a correlation between its elevated peripheral levels and psychosis in the adult offspring [53]. Except for one meta-analysis by Pillinger et al., which showed no alterations in IL-8 peripheral levels compared to HC [37], research consistently suggests its elevated peripheral levels in FEAN [12,16] and ARCh patients [12,14,41] but not in medicated FEP populations [54]. In turn, no alterations are found in CHR and UHR populations [38,39]. None of the available meta-analyses present evidence of its peripheral levels in SCh.

The IL-8 peripheral concentration shows a positive correlation with negative symptom severity and the overall psychopathological presentation [45]. Patients with elevated IL-8 levels improve more slowly during treatment, and have a poorer prognosis for negative symptoms [45]. IL-8 levels appear to increase with disease duration [45].

Where no stratification is considered, either by patient population or administered pharmacological treatment, antipsychotic medications do not seem to affect peripheral levels of IL-8 [48]. Likewise, such an effect is not observed when considering only FEAN patients or only those treated with risperidone [48].

\subsection{Interleukin-10}

IL-10 is one of the primary anti-inflammatory cytokines secreted mostly by activated regulatory $\mathrm{T}$ (Treg), Th2 lymphocytes and regulatory B lymphocytes [55]. It reduces the 
production of reactive oxygen species and contributes to reduced oxidative stress [56]. It also reduces the secretion of IFN- $\gamma$ and IL- 2 by Th1 lymphocytes and pro-inflammatory cytokines by macrophages [34].

Although one meta-analysis by Goldsmith et al. showed elevated levels of IL-10 in the blood of FEAN patients [14], two later ones by Pillinger et al. and Çakici et al. involving larger samples indicated its unchanged levels in this cohort relative to HC $[16,37]$. Interestingly, ARCh patients seem to have reduced peripheral IL-10 levels versus HC, but such observations are reported in only two studies with relatively small samples [12,14]. Only one meta-analysis by Goldsmith et al. considered IL-10 peripheral levels in SCh patients, demonstrating their unaltered peripheral levels [14]. Similarly, peripheral levels of IL-10 also appear to be unchanged relative to HC in the CHR and UHR populations $[38,39]$. Interestingly, reduced IL-10 peripheral levels relative to both other adult AChRs and HCs were demonstrated in AChR patients with early-onset psychosis [40], which is inconsistent with the results reported in other works [12,14].

A positive correlation has been found between peripheral levels of IL-10 and negative symptom severity, general psychopathological presentation, attention deficits and incidence of aggressive behaviors, and a negative correlation with cognitive deficits [45].

Available meta-analyses in which no stratification by treatment or patient population has been applied suggest no effect of antipsychotic medications on peripheral IL-10 levels [48,49]. Similar observations were made for the FEAN and ARCh populations [48]. However, in their meta-analysis employing a much larger sample, Marcinowicz et al. showed decreasing peripheral levels of IL-10 in response to antipsychotic treatment [51]. Stratification by treatment revealed that risperidone lowers, aripiprazole elevates, while quetiapine has no effect on IL-10 levels [48].

\subsection{Interleukin-12}

Secreted mainly by macrophages and dendritic cells in response to components of the bacterial cell wall, IL-12 stimulates proliferation, and activates and increases the cytotoxicity of NK and T cells, promoting the differentiation of the latter into Th1. It is also known to induce the secretion of IFN- $\gamma$ and TNF- $\alpha$, and has a synergistic effect with IL-18 [34,57].

Although in their meta-analysis Miller et al. showed increased IL-12 peripheral levels in FEAN compared to HC [12], further meta-analyses by Goldsmith et al. and Çakici et al. based on much larger samples found no such alterations [14,16]. Only the meta-analysis by Miller et al. investigated variations in IL-12 peripheral levels in a SCh population, failing to show any differences in relation to HC [12]. Likewise, there was no evidence of alterations in IL-12 CSF levels [12]. Reduced IL-12 levels were reported in chronic EOP patients, but not in CHR [38-40].

IL-12 peripheral levels appear to correlate with cognitive deficits [45].

Meta-analyses of the effect of antipsychotics on IL-12 peripheral levels where no stratification by population or administered pharmacotherapy is applied seem to yield inconsistent results, suggesting their elevated [12,14,49] or unaltered values [48]. In addition, in their meta-analysis including the largest sample, Romeo et al. described no changes in IL-12 peripheral levels in ARCh patients, and their elevated values in those treated with risperidone [48].

\subsection{Interleukin-17}

IL-17 is secreted by helper lymphocytes 17 (Th17) and stimulates, among others, macrophages and microglia to secrete proinflammatory cytokines [34].

In their meta-analyses both Goldsmith et al. and Fang et al. showed no alterations in IL-17 peripheral levels in FEAN patients compared to HC [14,15]. Nevertheless, the most recent meta-analysis by Pillinger et al., based on the largest sample, found its elevated peripheral levels in the FEAN population [37]. 
Studies indicate a positive correlation of IL-17 with positive symptom severity and overall psychopathological presentation, as well as incidence of aggressive behaviors, and a negative correlation with negative symptoms [45-47].

To date, no effect of antipsychotics on peripheral IL-17 levels has been demonstrated $[12,48,50,51]$.

\subsection{Interleukin-18}

Interleukin 18 (IL-18) is a pro-inflammatory cytokine produced by macrophages and dendritic cells and astrocytes, as well as in several types of epithelial cells [34]. By interacting with IL-12 or IL-15, it induces the secretion of IFN- $\gamma$ by Tc lymphocytes and NK cells, and stimulates the differentiation of Th1 lymphocytes [57], while where no such interactions occur, it mediates the differentiation of T cells into Th2 cells [34,57].

To date, only one meta-analysis by Goldsmith et al. considered IL-18 peripheral levels in psychosis, including only the FEAN population and demonstrating its unaltered levels in this cohort compared to HCs [14]. There are some reports of elevated [58] and unchanged [59] IL-18 levels in the EOP population, as well as in the ARCh patients [60]. The IL-18-binding protein (IL-18BP), whose main role is probably to blunt IL-18 and Th1 activity in order to prevent autoimmune response, may also be of importance in schizophrenia [57]. An elevated ratio of IL-18 to IL-18BP has been demonstrated in EOP, thus suggesting the increased biological activity of IL-18 in this patient population [59].

Peripheral levels of IL-18 seem to decrease in response to antipsychotics in the AChR population [60].

A correlation between peripheral levels of IL-18 and the severity of depressive symptoms was found in EOP, which is probably related to the increased cortisol level [59].

\subsection{Tumor Necrosis Factor $\alpha$}

Produced predominantly by macrophages (18), for which it is a chemotactic factor, TNF- $\alpha$ increases their cytotoxicity and the ability of the entire immune system to induce oxidative stress [56]. Many other cytokines, including IL-1, IL-6, and IFN- $\gamma$, are secreted in response to TNF- $\alpha$ [34]. Produced also by microglia, TNF- $\alpha$ increases the mortality of hippocampal stem cells, affects neuroplasticity, and reduces neurogenesis [29]. Soluble TNF receptors (sTNF-R2, sTNF-R) have proven neuroprotective and immunosuppressive effects [61].

Available meta-analyses consistently report elevated peripheral TNF- $\alpha$ levels in FEAN [12-14,16,37] and AChR [12,14]. Conversely, although one meta-analysis by Miller et al. showed unaltered TNF- $\alpha$ levels in the SCh population [12], another one by Goldsmith et al., based on a larger sample, suggested its elevated peripheral levels [14]. Recent evidence appears to yield even more inconsistencies, demonstrating reduced TNF- $\alpha$ peripheral levels relative to controls in both EOP and ARCh patients [38], and no changes in the CHR population $[39,40]$.

There is a positive correlation between peripheral TNF- $\alpha$ levels and negative symptom severity, as well as a negative correlation with positive symptoms in all populations, general psychopathology in AChR, and cognitive deficits [45].

Meta-analytical data, where no stratification by patient has been performed, suggest that antipsychotics do not affect the peripheral levels of TNF- $\alpha[12,14,48,49]$. Authors are also consistent in reporting a lack of such effects in the FEAN population $[48,50]$, and reduced TNF- $\alpha$ levels in response to antipsychotic medication in the ARCh group [48]. Likewise, Marcinowicz et al. also demonstrated decreased peripheral levels of TNF- $\alpha$ in the patients treated with antipsychotics [51]. Stratification by treatment suggests that olanzapine can lower the levels of TNF- $\alpha$ in the blood, but no similar effect is found for risperidone, quetiapine, aripiprazole or clozapine [48]. Antipsychotics also elevate peripheral levels of sTNF-R1 and sTNR-R2. In the case of the latter, the effect is reported without considering any stratification of patients, and in the case of both receptors, drugresistant patients or those treated with clozapine [48]. 


\subsection{Interferon $\gamma$}

Interferon $\gamma(\mathrm{IFN}-\gamma)$ is produced by T lymphocytes, NK and NKT cells activated by the action of other cytokines (IL-2, IL-12, IL-15, IL-18, IL-21) (18). IFN- $\gamma$ is involved in stimulating the antiviral response and is an activator of macrophages, increasing their cytotoxicity. Moreover, it induces the secretion of IL-6, IL-15 and TNF- $\alpha$ [34].

Meta-analyses of IFN- $\gamma$ blood levels in the FEAN population yield inconsistent results, demonstrating their elevated [12,14,37] or unaltered values compared to HCs [13,16]. Elevated IFN- $\gamma$ levels compared to HCs are reported in AChR patients [12,14]. As regards the SCh population, meta-analytical data are inconsistent, suggesting unaltered [12] or reduced IFN- $\gamma$ peripheral levels compared to HCs [14]. No IFN- $\gamma$ alterations of any type were found in the CHR or UHR populations $[38,39]$. IFN- $\gamma$ peripheral levels correlate with positive symptom severity and general psychopathology in the FEAN population [45-47]. More pronounced negative symptoms are observed in patients with higher peripheral levels of IFN- $\gamma[46,47]$

Two meta-analyses wherein no stratification by population or treatment was performed found no changes in IFN- $\gamma$ peripheral levels in schizophrenia patients compared to HCs [12,14], but two others based on larger samples suggested their reduced values in the patient population [48,49]. Both Capuzzi et al. and Romeo et al., detailing the effects of antipsychotics on the FEAN cohort, have shown that IFN- $\gamma$ levels do not change in response to treatment $[48,50]$. However, they do seem to decrease in ARCh patients [14] and the FEP population [51]. Where stratification by treatment was applied, a decrease in peripheral IFN- $\gamma$ levels was demonstrated in response to therapy with olanzapine, but not risperidone, quetiapine or aripiprazole [48].

\subsection{Transforming Growth Factor $\beta$}

Transforming growth factor $\beta$ (TGF- $\beta$ ) is an anti-inflammatory cytokine produced by macrophages, neutrophils, platelets and lymphocytes. It inhibits the proliferation of $B$ and T lymphocytes, as well as NK cells. Instead, it increases Treg and Th17 lymphocytes and reduces the secretion of numerous cytokines [34].

Although three meta-analyses suggest elevated TGF- $\beta$ peripheral levels in FEAN patients compared to HCs $[12,14,37]$, another one demonstrates their unaltered values in the same patient group [16]. Elevated TGF- $\beta$ levels were found also in ARCh patients [12,14], but no alterations in their values were reported in the SCh population [12].

General psychopathology is reported to correlate with TGF- $\beta$ levels $[45,47]$. Furthermore, more severe negative symptoms are observed in patients with higher peripheral levels of TGF- $\beta$ [46].

Although one meta-analysis wherein no stratification by patient population was applied showed reduced peripheral levels of TGF- $\beta$ after the administration of antipsychotics [12], three subsequent ones, based on larger samples, did not confirm such an effect $[14,48,49]$. Similarly, considering only the ARCh population, the meta-analysis by Romeo et al. showed no alterations in peripheral levels of TGF- $\beta$ in response to antipsychotic treatment [48].

\subsection{Chemokines}

Chemokines are a family of cytokines that are mainly chemotactic factors for cells of the immune system, three of which appear to play a role in schizophrenia [54]. Monocyte chemoattractant protein 1 (MCP-1, CCL2) is a chemokine induced mostly by pro-inflammatory cytokines (e.g., IL-1, IL-4, TNF- $\alpha$, IFN- $\gamma$ ), but also by growth factors, lipopolysaccharides, reactive oxygen species and the immune complex [62]. MCP-1 interaction with CC chemokine receptor 2 leads to the activation of specific intracellular pathways, recruiting monocytes into sites of inflammation [62]. Moreover, MCP-1 plays an important role in the differentiation of T helper (Th) lymphocytes toward a Th1 or a Th2 phenotype [62]. Macrophage inflammatory protein $1 \beta$ (MIP-1 $\beta$, CCL4), which binds to CCR5, induces lymphocyte migration and adhesion, as well as the activation of ROS production [63,64]. In turn, eotaxin (CCL11) is mostly 
recognized as an eosinophile-specific chemokine related to complement component 3 [65]. The receptor for eotaxin is also expressed on basophiles, mast cells and Th2 lymphocytes, impacting their immune response [66].

The relationship of schizophrenia with peripheral chemokine levels has not been studied as extensively as the effect of non-chemokine cytokines on its course and development [54]. In addition to the previously reported IL-8 alterations, Frydecka et al. showed elevated peripheral levels of MCP-1, MIP- $1 \beta$ and eotaxin, where no stratification by patient group was applied, as well as elevated levels of MCP-1 in FEP, and MCP-1 and eotaxin in ARCh [54]. Interestingly, Misiak et al. also indicated an elevated concentration of MCP-1 in the blood of UHR [39].

\section{Immunogenetics of Cytokine Alternations in Schizophrenia}

The role of immunological dysfunction in the etiopathogenesis of schizophrenia is also demonstrated by its association with disorders of known autoimmunological underpinnings [67]. Schizophrenia has been shown to be associated with major histocompatibility complex A gene (MHC-A) polymorphisms [68], and with rheumatoid arthritis through major histocompatibility complex class II (MHC-II) or DRB1 $\beta$ chain gene (HLA-DRB1) [7].

Schizophrenia has also been shown to be associated with polymorphisms of numerous genes responsible for the synthesis of such cytokines as IL1A, IL1B, IL10 and IL6, which are genes for, respectively, IL- $1 \alpha$, IL-1 $\beta$, IL-10 and IL-6 [67,68]. The polymorphism of the IL6 $(-174 \mathrm{G} / \mathrm{C})$ gene does not elevate the level of IL-6 in the serum, but it has been shown to be associated with the occurrence and severity of positive symptoms in the course of schizophrenia [69]. Polymorphisms of TGFB1, which encodes TGF- $\beta$, along with its additional overexpression [70] were also associated with schizophrenia [71]. Quite remarkably, polymorphisms of the TNFR2 gene encoding the TNF- $\alpha$ receptor, depending on the variant, may be associated with an increased risk of schizophrenia, or may have a protective effect [72].

\section{The Role of Early Childhood Trauma}

Early childhood trauma has been associated with elevated peripheral levels of IL-6 and a faster elevation in IL- 6 and IL-1 $\beta$ levels with age in healthy adults, which, in the case of IL-6, also seems to have an impact on neurophysiology, but not IQ [73-76]. Experiencing any type of trauma in early childhood seems to lead to elevated peripheral levels of TNF- $\alpha$ and IL-6 in adults, while being a victim of sexual abuse only elevates peripheral levels of TNF- $\alpha$ in adulthood [77]. The nature of the relationship between early childhood trauma and cytokine levels also seems to depend on a number of factors, such as the nature of the trauma, applied diagnostic categories, age, menopause, and gender [77-79].

A study by Dennison et al. showed that only those schizophrenia patients who experienced childhood trauma had elevated levels of TNF- $\alpha$ and IL-6, while those who did not report such experience had levels of these cytokines similar to the control group [80]. Another study by Di Nicola et al. showed that although all FEP patients had elevated cytokine levels relative to the control group, those who experienced childhood trauma had higher serum TNF- $\alpha$ levels than those who did not [81]. The effect of childhood trauma on the elevated expression of IL-6 seems to be greater in schizophrenic patients than in the healthy controls, although such observations were based on small control and research groups [82]. A recent study by Corsi-Zuealli et al. conducted on a much larger sample of FEAN patients and $\mathrm{HC}$, including healthy siblings of patients, showed that the peripheral levels of TGF- $\beta$ in participants who had experienced physical abuse in childhood were significantly elevated in patients and their siblings compared to the controls. Moreover, patients who experienced physical abuse had higher levels of TGF- $\beta$ than those who did not. This study suggests that elevated peripheral levels of TGF- $\beta$, but not IL-6, IL-1 $\beta$, TNF- $\alpha$, IFN- $\gamma$ or IL-10, may not only predispose one to the development of schizophrenia, but may also be a consequence of childhood trauma [83]. Childhood trauma also seems 
to play a mediating role between elevated TNF- $\alpha$ levels and the changes in gray matter visible in MRI studies in patients with schizophrenia [84].

\section{Gut Microbiome Dysbiosis in Schizophrenia}

Gut microbiome dysbiosis affects behavior as well as the functioning and maturation of microglia $[85,86]$. Dysbiosis may also influence the activity of astrocytes with the participation of type I interferons and tryptophan metabolites [87]. Disturbances in the composition of the intestinal microbiome are associated with an increased permeability of the intestinal epithelium for bacteria, their antigens, and pathogen-associated molecular patterns (PAMPs), e.g., LPS. Greater permeability, in turn, correlates with elevated peripheral cortisol levels and could lead to the activation of the immune system related to the secretion of pro-inflammatory cytokines, activation of the HPA axis and the creation of a positive feedback loop [88-91].

In schizophrenia, there are differences in the composition of the microbiome compared to healthy controls, both in the oropharynx and in the intestines [26,27,92]. Gut microbiome biodiversity is greater in patients with schizophrenia, and shows a negative correlation with the number of CD8+ memory T cells in the blood [28]. The population size of individual bacterial species in the microbiome also correlates with symptom severity, and disturbances in its composition may be a marker of response to pharmacotherapy in FEP [93]. Moreover, an altered composition of gut microbiota persists despite treatment with olanzapine, which does not appear to have a significant effect on it [94]. Although there is no evidence of a beneficial effect of probiotic supplementation on schizophrenia symptom severity, it seems possible to use microbiome tests as an auxiliary tool in the diagnosis of the disease [27,95]. Further research is required to establish whether and to what extent dysbiosis may be responsible for the disturbances in the cytokine system present in patients with schizophrenia.

\section{Association of Alterations in the Cytokine Network with Neuroimaging}

Changes in the structure of the brain in patients with diagnosed schizophrenia are well reported in the literature [96]. Reduced gray matter and enlarged ventricles are described in FEP patients [97]. Additionally, within the white matter, there are also many aberrations that suggest impaired connectivity between different areas of the brain [98].

There is a growing body of evidence for a relationship between alterations in cytokine levels and the structure of gray and white matter of the brain in schizophrenia. Cytokines that can easily penetrate the blood-brain barrier induce reactions that can cause a cascading inflammatory response within the central nervous system [11], which leads to the activation of microglia and a reduction in the number of astrocytes, neurotoxicity, abnormal synaptic pruning or nerve cell apoptosis [11,99].

Elevated levels of pro-inflammatory cytokines (IL- 6 and TNF- $\alpha$ ) correlate with altered gray matter [84]. The level of IL-6 turns out to be significantly correlated with cortical thickness in the left pars opercularis, right pars triangularis, left superior temporal gyrus, and right middle temporal gyrus [100]. Other reports show a negative correlation between elevated levels of IL-1 $\beta$ mRNA (peripherally tested) and a reduced volume of Broca's area and verbal fluency in schizophrenia [101]. On the other hand, Hoseth et al. found no relationship between the structure or the volume of the hippocampus and plasma cytokine levels [102]. There is evidence that fetal exposure to elevated levels of IL-8 in maternal serum leads to reduced volumes of posterior cingulate and left entorhinal cortex, and increased volumes of ventricular cerebrospinal fluid, in patients with schizophrenia [103]. Neuroinflammation may also be associated with disorders of the white matter, and thus be the cause underlying altered brain connectivity [104]. It can lead to axonal degeneration, destruction of myelin and reduction of the number of oligodendrocytes. Changes in water anisotropy within the white matter fibers (which may be associated with altered white matter quality and lead to disturbances in connections between different areas of the brain [105]) may correlate with IL-6 levels in patients with schizophrenia [106]. As 
reported by Di Biase, peripheral levels of IL- 6 and TNF- $\alpha$ correlate with the amount of free water (FW). The increase in FW is sometimes associated with inflammation, and is found within white matter in patients with schizophrenia [107]. However, whether this type of neuroinflammation may lead to direct changes in white matter remains unresolved [8]. All in all, the relationship between altered cytokine levels and structural changes in the brain is still unclear.

\section{Glial Dysfunction}

The dysfunction of glial cells, which are the second component of nervous tissue besides neurons, is proposed as one of the key elements of the etiopathogenesis of schizophrenia, and at least some of the abnormalities affecting them may be mediated by cytokines [108]. Both autopsy examinations of brains [109] and positron emission tomography (PET) using the TSPO marker (18 kDa translocator protein) indicate the excessive activation of microglia, myeloid immune cells of the nervous system, in schizophrenia [110]. As mentioned, the pathological activation of microglia induced by pro-inflammatory cytokines could be associated with the abnormal pruning of neurons, as well as with the increased mortality of astrocytes, oligodendrocytes, neurons, and structural changes in both white and gray matter, demonstrated by neuroimaging studies in patients with schizophrenia [104,109]. Abnormal maturation and microglia activation could be associated with elevated levels of IL-6 and TGF- $\beta$ in the course of schizophrenia $[14,16,111,112]$.

However, cytokines may also have a detrimental effect directly on astroglial metabolism, for example, on the regulation of the kynurenine pathway, which is particularly active in this cell population [113]. The main regulatory enzyme of this pathway, indoleamine-2,3oxidase (IDO), is induced by IFN- $\gamma$, the effect of which may be counteracted by IL- 4 and IL-10 and enhanced by IL-1 $\beta$ [114]. Changes in the activity of IDO and other enzymes of the kynurenine pathway caused by disturbances in the cytokine network lead to an increased accumulation of kynurenic acid, the levels of which are increased in the CSF, brain tissue and blood of patients with schizophrenia [33,114,115]. Kynurenic acid is an NMDAR antagonist, and although physiologically it may protect against glutamate excitotoxicity, its excess may lead to NMDAR hypofunctionality, contributing to further increases in oxidative stress, the intensification of neuroinflammation, as well as disorders of the glutamine-glutamate cycle and the improper regulation of glutamatergic metabolism, ultimately exacerbating exotoxicity [6,116,117]. Parvalbumin interneurons (PVI), which play a key role in the regulation of dopaminergic pathways, whose dysfunction has a proven role in the development of schizophrenia symptoms, could be particularly sensitive to the consequences of such astrocyte dysfunction $[6,117]$. In addition, IL-1 $\beta$ increases the expression of FOXP3 and CCL20 genes, the roles of which are also postulated in the etiopathogenesis of schizophrenia, more in patient astrocytes than in HC astrocytes. [118]. Altered patterns of gene expression and astrocyte differentiation could also contribute to disorders of oligodendrocyte maturation and abnormal myelination [108].

\section{The Role of Nuclear Factor- $\kappa B$ and Human Endogenous Retroviruses}

Nuclear factor- $\kappa B(\mathrm{NF}-\kappa \mathrm{B})$, which mediates the increase in the secretion by microglia of such cytokines as IL- $1 \beta$ and IL-18 and is activated by IL- $1 \beta$, TNF- $\alpha$, PAMP, adrenal cortex hormones and adrenaline, may play an important role in the potential pathological feedback loop associated with disturbances in the cytokine network in schizophrenia [119]. The increased expression of NF- $\mathrm{KB}$ and related receptors and kinases in the cerebral cortex compared to $\mathrm{HC}$ is confirmed by autopsy studies of the brains of people diagnosed with schizophrenia $[120,121]$. Elevated levels of IL-1 $\beta$ and TNF- $\alpha$, well documented in meta-analytic data, could therefore partially result from or be the cause of increased NF- $\kappa B$ activity $[14,16,119]$. Other factors influencing the increased activation of NF- $\kappa B$ could also include the well-confirmed increased blood cortisol levels in patients with schizophrenia [122], the indirect dysbiosis of the intestinal microbiome [123], and, with the participation of epigenetic mechanisms, early childhood trauma [124]. 
Human endogenous retroviruses (HERVs) are a group of viruses that infected germinal cells of mammals many millions of years ago and were permanently integrated into their genome [125]. Under the influence of viral infections, for example, with EpsteinBarr viruses (EBV) and Herpes simplex type 1 (HSV-1), some HERVs may reactivate, the role of which has been proposed, for example, in the etiopathogenesis of multiple sclerosis $[126,127]$. HSV-1 infections, similarly to other infections during pregnancy and birth in the fall and winter, when such infections are more frequent, are a confirmed risk factor for the development of schizophrenia in the offspring [128]. HSV-1 exposure is also associated with greater cognitive deficits in the course of schizophrenia [129]. It has been suggested that HERVs reactivation may be mediated by NF- $\mathrm{kB}$ with the involvement of TNF- $\alpha$ and INF- $\gamma$, whose peripheral levels are elevated in schizophrenia $[14,130,131]$. In turn, the increase in HERVs expression may be associated with both an increase in the expression of pro-inflammatory cytokines and the activation of microglia, thus creating another pathological positive feedback loop [132,133]. Moreover, one of the HERVs, HERV$\mathrm{W}$, increases the expression of TNF- $\alpha$ and IL-10 in glial cells by inhibiting MyD88s, which is a splice variant of the activator NF- $\mathrm{KB}$ (MyD88), which in turn is activated, inter alia, by IL$1 \beta$ [134-136]. It has been proposed that the activation of microglia and peripheral myeloid cells caused by HERVs reactivation could lead to an increase in oxidative stress, and thus damage to astrocytes, disturbance of their function, and abnormal myelination [125].

A study by Karlsson et al. demonstrated HERV-W expression in FEP patients, which is absent in HCs [137]. Similarly, although based on a rather small sample, a post-mortem study by Frank et al. indicated an increased expression of HERV-K10 in the brains of schizophrenia patients [138]. HERV-K methylation in the genetic material obtained from peripheral blood leukocytes is also significantly lower in both FEP and ARCh patients compared to HC [139]. In addition, the increased expressions of HERV-K and HERV-W are also correlated with increased expressions of DISC1, PRODH, BDNF and D3 genes, which are associated with susceptibility to schizophrenia $[125,140,141]$. Interestingly, the presence of HERV-W antigens in the peripheral blood was also associated, in at least a certain subpopulation of schizophrenic patients, both with elevated peripheral levels of IL-6 and a higher incidence of early childhood trauma resulting from emotional abuse [142].

\section{Patient Stratification}

To date, it has not been established whether cytokine disturbance in schizophrenia occurs in all affected patients, or whether it is rather specific to an "immune" subpopulation thereof. Determining possible patient phenotypes is therefore among the most important research goals. A meta-analysis by Pillinger et al. showed a reduced variability of IL-1 $\beta$, IL-4, IL-6, IL-8 and TNF- $\alpha$ levels in FEP compared to the control group, which, along with the unimodality of the distributions, could suggest the absence of an immune subgroup of patients and the prevalence of cytokine dysregulation in patients with schizophrenia [37]. Cluster analysis allowed the identification of four subpopulations of FEAN patients with different symptom profiles, with a population with the highest symptom severity characterized by elevated peripheral levels of IL-7, IL-15, IL-17, IFN- $\gamma$, TNF- $\alpha$, soluble intracellular adhesion molecule 1 (sICAM-1) and soluble vascular cell adhesion molecule 1 (sVCAM-1), and the lowest symptom severity population with reduced CXCL12 or elevated IL-8 peripheral levels, compared to the other subpopulations [143].

Due to the heterogeneity of schizophrenia, numerous efforts have been made to distinguish its different subtypes. One such subtype was described in 1988 by Carpenter et al. as deficit syndrome [144], characterized by the presence of negative symptoms (diminished emotional range, restricted affect, diminished sense of purpose, poverty of speech, diminished social drive, curbing of interests), which must be persistent, present for 12 months, and primary (independent of treatment and depressive symptoms, or not due to positive symptoms) [145]. Apart from the characteristic psychopathological presentation, differences in cytokine levels also suggest the presence of a particular schizophrenia subtype. It has been reported that IL-17 elevated peripheral levels compared to HC in 
deficit schizophrenia [146]. Garcia-Rizo et al. demonstrated higher IL-6 and CRP levels in drug-naive patients with features of deficit syndrome compared to patients with diagnosed schizophrenia [147]. It therefore seems that the peripheral levels of IL-6 and TNF- $\alpha$ may be closely related with the deficit subtype [148].

\section{Conclusions}

In research on schizophrenia, attempts are often made to divide various types of deviations from HC into trait markers that are associated with hereditary and neurodevelopmental factors, and thus susceptibility to the disease, and state markers associated with the disease itself and its symptoms [149]. As available meta-analyses are often inconsistent in distinguishing trait and state markers, we have made an attempt to resolve this issue, using specific criteria. Therefore, we assumed that in order to define an alteration in the peripheral levels of a given cytokine in patients with schizophrenia relative to $\mathrm{HC}$ as a trait marker, the following criteria should be met:

(1) Evidence of altered levels of a given cytokine in patients with schizophrenia and in the CHR/UHR population;

(2) Evidence of alterations in both psychosis and remission;

(3) Evidence of alterations in all patient populations.

In the case of discrepancy between meta-analyses, we preferred those based on larger samples for a given cytokine.

Following these criteria, the only cytokine with elevated peripheral levels that can be distinguished as a trait maker based on the results of meta-analyses by Goldsmith et al., Misiak et al. and Çakici et al. is IL-6 [14,16,39]. Although the meta-analysis by Miller et al. yields conflicting results [12], meta-analyses by Goldsmith et al. [14] and Çakici et al. [16],; including much larger patient samples and studies on the CHR/UHR populations, seem to confirm such a proposal [38,39]. It is also supported by larger studies of CSF levels [41-43].

Elevated peripheral levels of MCP-1 are also a potential trait marker; however, despite evidence from the FEP population, meta-analytic data on FEAN are lacking [54]. Based on the meta-analysis by Goldsmith et al., trait markers could also be elevated peripheral levels of IL-1 $\beta$ and TNF- $\alpha$ [14]; however, in their case there is no confirmation in the meta-analyses of peripheral levels in the CHR/UHR population [38,39]. Similarly, elevated levels of sIL2-R could be a trait marker of schizophrenia [13,14], but meta-analyses in the CHR/UHR populations did not include them $[38,39]$. In the case of IL- $1 \beta$, IL- 6 and TNF- $\alpha$, their potential roles as trait markers of schizophrenia seem to be supported by correlations with the results of neuroimaging studies [84,100-105],; and in the case of TNF- $\alpha$ and IL-6, also with the experience of early childhood trauma $[80,81]$.

In order to define an alteration in the peripheral levels of a given cytokine in patients with schizophrenia relative to $\mathrm{HC}$ as a state marker, only one of the following criteria should be met:

(1) Evidence of alternated peripheral levels in acute psychosis (FEAN, FEP, ARCh), but not in patients in remission (SCh);

(2) Evidence of inverse or no alterations in peripheral levels in stable chronic (SCh) and acute psychotic (FEAN, FEP ARCh) patients.

Again, in case of discrepancies between meta-analyses, we preferred those based on larger samples for a given cytokine.

According to these criteria and based on the meta-analyses by Miller et al. and Goldsmith et al. [12,14],; state markers of schizophrenia may include elevated peripheral levels of IFN- $\gamma$ and TGF- $\beta$, while lower IFN- $\gamma$ levels relative to HCs observed in remission [14] may be the result of pharmacotherapy [48]. It is also possible that IL-4 and IL-10 are state markers of ARCh, but not of FEP/FEAN [12,14,37], which seems to be consistent with the different effects of antipsychotics on IL-4 levels in FEAN and ARCh, and with the different effects of individual medications on the levels of IL-10 in the blood [48]. 
Peripheral levels of IL-1 $\beta$, IL-6, IL-8, IL-10, IL-17 and IFN- $\gamma$ show a positive correlation, and peripheral levels IL-2 and TNF- $\alpha$ have a negative correlation, with the intensity of positive symptoms [45-47]. Peripheral levels of IL- $1 \beta$, IL-6, TNF- $\alpha$, IFN- $\gamma$ and TGF- $\beta$ correlate positively, and IL-17 correlates negatively, with the intensity of negative symptoms [45-47]. In turn, cognitive impairment seems to correlate with peripheral levels of IL-1 $\beta$, IL-4, IL- 6 and IL-12, and considering only the AChR population, also with peripheral levels of TNF- $\alpha$ [45]. There is also a negative correlation of cognitive dysfunction with the peripheral levels of IL-2 and IL-10; the more frequent occurrence of aggressive behavior is associated with increased levels of IL-10 and IL-17, and the greater incidence of depressive symptoms with increased peripheral levels of IL-4 and IL-18 [45].

Meta-analyses wherein no stratification by specific medications or patient population was applied suggest that the peripheral levels of IL- $1 \beta$, TGF- $\beta$ and IFN- $\gamma$ decreased in response to antipsychotics $[12,14,48,49]$. It is less clear whether the levels of IL-6 or IL-4 in the blood also decrease, but meta-analyses based on larger samples did not show such changes $[12,14,48,49]$. This would be consistent with the fact that elevated IL-6 peripheral levels seems to be a trait marker of schizophrenia $[14,39]$. On the contrary, peripheral levels of sIL-2R and sTNF-R2 elevate with antipsychotic treatment, which is not unequivocal in the case of IL-12 $[12,14,48,49]$. In the first episode, antipsychotics seem to have a slightly different effect than in others, with decreasing peripheral levels of IL-4, IL-6, and possibly also IL-1 $\beta[12,14,48,50]$. Despite some contradictory results, meta-analyses based on the largest research groups indicate that in this population, the level of IL-2 in the blood does not change under the influence of medication in the first episode $[12,14,48,50]$. The results concerning decreasing peripheral levels of IL-10, TNF- $\alpha$ and IFN- $\gamma$ are less consistent, showing both decreasing and unaltered levels [12,14,48-50]. Only one meta-analysis of the influence of antipsychotics on the levels of cytokines by Romeo et al. took into account the population of patients in further episodes, and showed decreasing levels of IL-1 $\beta$, IL-6, sIL-6R, TNF- $\alpha$ and IFN- $\gamma$ in this population [48]. In conclusion, the results of the metaanalyses to date seem to suggest that the influence of antipsychotics on cytokine levels may differ during the course of schizophrenia, potentially contributing to the phenomenon of drug resistance, but still, the number of studies including chronic patients is insufficient to confirm this [14,48-50,52]. Risperidone seems to have the most notable effect on cytokine levels by lowering the levels of IL- $1 \beta$, IL-2, IL-4, IL- 6 and IL-10, and increasing the levels of IL-12 [48,52]. In addition, olanzapine appears to lower peripheral levels of IL-2, TNF- $\alpha$ and IFN- $\gamma$, while clozapine elevates levels of sIL-2R and TNF receptors, and haloperidol reduces levels of IL-2 [48].

Possible causes of altered levels of cytokines in blood and CSF include polymorphisms in their genes [67-69]. These polymorphisms could contribute to later sensitivity to the influence of other factors, such as early childhood trauma and HPA axis dysregulation [84],; or disturbances in the composition of the gut microbiota [26-28,92].

Currently, there is an insufficient variety of methods for the early diagnosis, prediction and prognosis of schizophrenia that are not based on symptomatology assessment, and a growing body of evidence suggests that cytokine peripheral levels testing could be used to fill this gap [45]. Potential trait markers, such as the previously mentioned elevated peripheral levels of IL-1 $\beta$, IL-6, MCP-1, TNF- $\alpha$ and sIL2-R, could be helpful in the early recognition of patients at risk of psychosis [12,14,39]. Potential state markers, such as elevated peripheral levels of IFN- $\gamma$ and TGF- $\beta$, could in turn be useful in detecting relapses $[12,14]$. Elevated IL-6, IL-8, IFN- $\gamma$ and soluble TNF receptor levels, as well as reduced peripheral levels of IL-2, have been reported as markers of poorer response to treatment with antipsychotics [45]. Elevated IL-7, IL-15, IL-17, IFN- $\gamma$ and TNF- $\alpha$ levels could be associated with poorer prognosis, while an elevated level of IL- 8 with better prognosis [143]. Additionally, IL-6 and TNF- $\alpha$ peripheral levels' testing could be used to predict future changes in the negative symptom severity in CHR [43]. It has also been proposed to use cytokine level testing to identify the age of onset in schizophrenia patients [40]. IL-4 seems to be the most promising candidate, offering relatively high sensitivity and 
specificity, and additional measurements of IL-1 $\beta$, IL-6, IL-10, IL-12 and TNF- $\alpha$ could further enhance the effectiveness of this approach [40].

Disturbances within the cytokine network that occur in the course of schizophrenia can be analyzed in the context of the research domain criteria framework (RDoC). The goal of $\mathrm{RDoC}$ is to define mental illnesses based on their biological signatures, not primarily on the clinical picture [150]. The RDoC matrix enables the analysis of disorders in specific domains (e.g., cognitive systems, systems of social processes) and levels (genes, molecules, cells, neurocircuits, physiology, behavior, self-reports), and the systematization of relationships between them [151].

While there is evidence of a role of disturbances in the cytokine network in schizophrenia at the gene level [67-69] and the level of individual molecules, such as NF- $\mathrm{kB}$ and HERVs $[133,134,137,140]$, the abnormal functioning of microglial cells, astrocytes, oligodendrocytes and neurons $[6,108,110,113]$, physiological markers in the form of altered levels of cytokines peripherally and in CSF [14,41], and their correlation with the intensity of symptoms in the classical sense diagnosed using scales and structured interviews $[9,45]$, there are deficiencies in research both on their relationship with the functioning of specific neurocircuits and in the relationships between individual levels in terms of proposed RDoC domains, rather than more traditional categories of psychopathological symptoms, such as positive or negative symptoms.

Considering that disturbances in the cytokine network (1) provide a chance to distinguish HC from schizophrenic patients [9,14,39], (2) allow us to distinguish groups of patients characterized by similar symptom profiles, including those diagnosed with deficit schizophrenia $[143,146,147]$, and (3) illustrate the different effects of individual antipsychotic drugs on the peripheral levels of various cytokines, the knowledge of the profile of disturbances in the cytokine network in a given patient could enable the selection of personalized treatment $[48,51]$. Designing future research with the RDoC framework in mind could significantly contribute to the development of specific clinical applications and a better understanding of immune disorders in schizophrenia.

Our paper has certain limitations, mainly due to the fact that we have not used any more systematic form of searching for papers relevant to the issue. Therefore, the limitations of our work are typical for a narrative review [152]. Although we have not included all publications related to the topic of cytokine network alterations in schizophrenia, mainly due to their great number and diversity, given that the multitude of papers cited in our narrative review often obtained contradictory results despite the use of protocols for metaanalyses and systematic reviews, our approach can provide a more accessible and holistic source of information on the current state of knowledge for clinicians and researchers less familiar with the topic. Taking into account the potential future applications of knowledge about the alterations in the cytokine network in schizophrenia in clinical practice and the dynamic development of the field, this may be of value for such readers. We would also like to point out that a significant part of the references cited by us are systematic reviews and meta-analyses, often published very recently, which reduces the risk of omitting relevant publications.

In this narrative review, we presented the most important publications on the disturbances in the cytokine system in the course of schizophrenia, and also presented possible relationships with other important fields of research on this disorder, such as the impact of early childhood trauma, disturbances in the gut microbiota, or neuroimaging. A growing body of evidence has shown the significant role of cytokines in the etiopathogenesis of schizophrenia, as well as their possible application in the diagnosis, prognosis and stratification of patients. Additionally, based on the currently available data, we have proposed the most reliable trait and state markers of schizophrenia.

Author Contributions: Conceptualization, B.D., A.G., P.P., Z.L., B.M. and J.S.; methodology, B.D. and P.P.; writing-original draft preparation, B.D., A.G. and P.P.; writing-review and editing, P.P., Z.L., B.M. and J.S.; supervision, P.P., B.M., J.S.; All authors have read and agreed to the published version of the manuscript. 
Funding: The project is financed from program of the Minister of Science and Higher Education under the name "Regional Initiative of Excellence" in 2019-2022 project number 002/RID/2018/2019 amount of financing 12000000.

Conflicts of Interest: The authors declare no conflict of interest.

\section{References}

1. Owen, M.J.; Sawa, A.; Mortensen, P.B. Schizophrenia. Lancet 2016, 388, 86-97. [CrossRef]

2. Haijma, S.V.; Haren, N.; van Cahn, W.; Koolschijn, P.C.M.P.; Pol, H.E.H.; Kahn, R.S. Brain Volumes in Schizophrenia: A Meta-Analysis in Over 18000 Subjects. Schizophr. Bull. 2013, 39, 1129-1138. [CrossRef]

3. Vita, A.; Peri, L.; de Deste, G.; Sacchetti, E. Progressive loss of cortical gray matter in schizophrenia: A meta-analysis and meta-regression of longitudinal MRI studies. Transl. Psychiatry 2012, 2, e190-e213. [CrossRef]

4. Lewandowski, K.E.; Cohen, B.M.; Öngur, D. Evolution of neuropsychological dysfunction during the course of schizophrenia and bipolar disorder Evolution of neuropsychological dysfunction during the course of schizophrenia and bipolar disorder. Psychol. Med. 2011, 41, 225-241. [CrossRef] [PubMed]

5. McGrath, J.; Saha, S.; Chant, D.; Welham, J. Schizophrenia: A concise overview of incidence, prevalence, and mortality. Epidemiol. Rev. 2008, 30, 67-76. [CrossRef] [PubMed]

6. Barron, H.; Hafizi, S.; Andreazza, A.C.; Mizrahi, R. Neuroinflammation and oxidative stress in psychosis and psychosis risk. Int. J. Mol. Sci. 2017, 18, 651. [CrossRef] [PubMed]

7. Crespi, B.J.; Thiselton, D.L. Comparative immunogenetics of autism and schizophrenia. Genes Brain Behav. 2011, $10,689-701$. [CrossRef]

8. Najjar, S.; Pearlman, D.M. Neuroin $\mathrm{fl}$ ammation and white matter pathology in schizophrenia: Systematic review. Schizophr. Res. 2015, 161, 102-112. [CrossRef]

9. Miller, B.J.; Goldsmith, D.R. Towards an Immunophenotype of Schizophrenia: Progress, Potential Mechanisms, and Future Directions. Neuropsychopharmacology 2017, 42, 299-317. [CrossRef]

10. Stuart, M.J.; Baune, B.T. Chemokines and chemokine receptors in mood disorders, schizophrenia, and cognitive impairment: A systematic review of biomarker studies. Neurosci. Biobehav. Rev. 2014, 42, 93-115. [CrossRef]

11. Rodrigues-Amorim, D.; Rivera-Baltanás, T.; Spuch, C.; Caruncho, H.J.; González-Fernandez, Á.; Olivares, J.M.; Agís-Balboa, R.C. Cytokines dysregulation in schizophrenia: A systematic review of psychoneuroimmune relationship. Schizophr. Res. 2017, 197, 19-33. [CrossRef] [PubMed]

12. Miller, B.; Peter, B.; Seabolt, W.; Mellor, A.B.K. Meta-Analysis of Cytokine Alterations in Schizophrenia: Clinical Status and Antipsychotic Effects. Biol. Psychiatry 2011, 70, 663-671. [CrossRef]

13. Upthegrove, R.; Manzanares-Teson, N.; Barnes, N.M. Cytokine function in medication-naive first episode psychosis: A systematic review and meta-analysis. Schizophr. Res. 2014, 155, 101-108. [CrossRef] [PubMed]

14. Goldsmith, M.H.; Rapaport, B.M. A meta-analysis of blood cytokine network alterations in psychiatric patients: Comparisons between schizophrenia, bipolar disorder and depression. Mol. Psychiatry 2016, 21, 1696-1709. [CrossRef] [PubMed]

15. Fang, X.; Zhang, Y.; Fan, W.; Tang, W.; Zhang, C. Interleukin-17 Alteration in First-Episode Psychosis: A Meta-Analysis. Mol. Neuropsychiatry 2017, 3, 135-140. [CrossRef] [PubMed]

16. Çakici, N.; Sutterland, A.L.; Penninx, B.W.J.H.; Dalm, V.A.; de Haan, L.; van Beveren, N.J.M. Altered peripheral blood compounds in drug-naïve first-episode patients with either schizophrenia or major depressive disorder: A meta-analysis. Brain. Behav. Immun. 2020, 88, 547-558. [CrossRef]

17. Pandey, G.N.; Ren, X.; Rizavi, H.S.; Zhang, H. Proinflammatory cytokines and their membrane-bound receptors are altered in the lymphocytes of schizophrenia patients. Schizophr. Res. 2015, 164, 193-198. [CrossRef]

18. Misiak, B.; Krefft, M.; Bielawski, T.; Moustafa, A.A.; Sasiadek, M.M.; Frydecka, D. Toward a unified theory of childhood trauma and psychosis: A comprehensive review of epidemiological, clinical, neuropsychological and biological findings. Neurosci. Biobehav. Rev. 2017, 75, 393-406. [CrossRef]

19. Lavratti, C.; Dorneles, G.; Pochmann, D.; Peres, A.; Bard, A.; de Lima Schipper, L.; Dal Lago, P.; Wagner, L.C.; Elsner, V.R. Exercise-induced modulation of histone $\mathrm{H} 4$ acetylation status and cytokines levels in patients with schizophrenia. Physiol. Behav. 2017, 168, 84-90. [CrossRef]

20. Varese, F.; Smeets, F.; Drukker, M.; Lieverse, R.; Lataster, T.; Viechtbauer, W.; Read, J.; Van Os, J.; Bentall, R.P. Childhood adversities increase the risk of psychosis: A meta-analysis of patient-control, prospective-and cross-sectional cohort studies. Schizophr. Bull. 2012, 38, 661-671. [CrossRef]

21. Thompson, A.D.; Nelson, B.; Yuen, H.P.; Lin, A.; Amminger, G.P.; McGorry, P.D.; Wood, S.J.; Yung, A.R. Sexual trauma increases the risk of developing psychosis in an ultra high-risk "prodromal" population. Schizophr. Bull. 2014, 40, 697-706. [CrossRef]

22. Misiak, B.; Frydecka, D. A history of childhood trauma and response to treatment with antipsychotics in first-episode schizophrenia patients. J. Nerv. Ment. Dis. 2016, 204, 787-792. [CrossRef]

23. Bailey, T.; Alvarez-Jimenez, M.; Garcia-Sanchez, A.M.; Hulbert, C.; Barlow, E.; Bendall, S. Childhood trauma is associated with severity of hallucinations and delusions in psychotic disorders: A systematic review and meta-analysis. Schizophr. Bull. 2018, 44, 1111-1122. [CrossRef] 
24. Gur, T.L.; Shay, L.; Palkar, A.V.; Fisher, S.; Varaljay, V.A.; Dowd, S.; Bailey, M.T. Prenatal stress affects placental cytokines and neurotrophins, commensal microbes, and anxiety-like behavior in adult female offspring. Brain Behav. Immun. 2017, 64, 50-58. [CrossRef]

25. Bailey, M.T.; Dowd, S.E.; Galley, J.D.; Hufnagle, A.R.; Rebecca, G.; Lyte, M. Exposure to social stressors alters the structure of the intestinal microbiota. Brain Behav. Immun. 2011, 25, 397-407. [CrossRef]

26. Yolken, R.H.; Severance, E.G.; Sabunciyan, S.; Gressitt, K.L.; Chen, O.; Stallings, C.; Origoni, A.; Katsafanas, E.; Schweinfurth, L.A.B.; Savage, C.L.G.; et al. Metagenomic sequencing indicates that the oropharyngeal phageome of individuals with schizophrenia differs from that of controls. Schizophr. Bull. 2015, 41, 1153-1161. [CrossRef]

27. Shen, Y.; Xu, J.; Li, Z.; Huang, Y.; Yuan, Y.; Wang, J.; Zhang, M.; Hu, S.; Liang, Y. Analysis of gut microbiota diversity and auxiliary diagnosis as a biomarker in patients with schizophrenia: A cross-sectional study. Schizophr. Res. 2018, 197, 470-477. [CrossRef] [PubMed]

28. Olde Loohuis, L.M.; Mangul, S.; Ori, A.P.S.; Jospin, G.; Koslicki, D.; Yang, H.T.; Wu, T.; Boks, M.P.; Lomen-Hoerth, C.; WiedauPazos, M.; et al. Transcriptome analysis in whole blood reveals increased microbial diversity in schizophrenia. Transl. Psychiatry 2018, 8, 1-9. [CrossRef] [PubMed]

29. Trovão, N.; Prata, J.; Vondoellinger, O.; Santos, S.; Barbosa, M.; Coelho, R. Peripheral biomarkers for first-episode psychosisopportunities from the neuroinflammatory hypothesis of schizophrenia. Psychiatry Investig. 2019, 16, 177-184. [CrossRef] [PubMed]

30. Allswede, D.M.; Buka, S.L.; Yolken, R.H.; Torrey, E.F.; Cannon, T.D. Elevated maternal cytokine levels at birth and risk for psychosis in adult offspring. Schizophr. Res. 2016, 172, 41-45. [CrossRef]

31. Zhang, J.; Luo, W.; Huang, P.; Peng, L.; Huang, Q. Maternal C-reactive protein and cytokine levels during pregnancy and the risk of selected neuropsychiatric disorders in offspring: A systematic review and meta-analysis. J. Psychiatr. Res. 2018, 105, 86-94. [CrossRef]

32. Purves-Tyson, T.D.; Weber-Stadlbauer, U.; Richetto, J.; Rothmond, D.A.; Labouesse, M.A.; Polesel, M.; Robinson, K.; Shannon Weickert, C.; Meyer, U. Increased levels of midbrain immune-related transcripts in schizophrenia and in murine offspring after maternal immune activation. Mol. Psychiatry 2021, 26, 849-863. [CrossRef]

33. Pedraz-Petrozzi, B.; Elyamany, O.; Rummel, C.; Mulert, C. Effects of inflammation on the kynurenine pathway in schizophreniaA systematic review. J. Neuroinflamm. 2020, 17, 1-17. [CrossRef] [PubMed]

34. Akdis, M.; Aab, A.; Altunbulakli, C.; Azkur, K.; Costa, R.A.; Crameri, R.; Duan, S.; Eiwegger, T.; Eljaszewicz, A.; Ferstl, R.; et al. Interleukins (from IL-1 to IL-38), interferons, transforming growth factor $\beta$, and TNF- $\alpha$ : Receptors, functions, and roles in diseases. J. Allergy Clin. Immunol. 2016, 138, 984-1010. [CrossRef] [PubMed]

35. Sokolowska, M.; Chen, L.; Liu, Y.; Martinez-Anton, A.; Qi, H.; Logun, C.; Alsaaty, S.; Park, Y.H.; Kastner, D.L.; Chae, J.J.; et al. Prostaglandin E 2 Inhibits NLRP3 Inflammasome Activation through EP4 Receptor and Intracellular Cyclic AMP in Human Macrophages. J. Immunol. 2015, 194, 5472-5487. [CrossRef] [PubMed]

36. Allswede, D.M.; Yolken, R.H.; Buka, S.L.; Cannon, T.D. Cytokine concentrations throughout pregnancy and risk for psychosis in adult offspring: A longitudinal case-control study. Lancet Psychiatry 2020, 7, 254-261. [CrossRef]

37. Pillinger, T.; Osimo, E.F.; Brugger, S.; Mondelli, V.; McCutcheon, R.A.; Howes, O.D. A Meta-Analysis of Immune Parameters, Variability, and Assessment of Modal Distribution in Psychosis and Test of the Immune Subgroup Hypothesis. Schizophr. Bull. 2019, 45, 1120-1133. [CrossRef]

38. Park, S.; Miller, B.J. Meta-analysis of cytokine and C-reactive protein levels in high-risk psychosis. Schizophr. Res. 2019, 226, 5-12. [CrossRef]

39. Misiak, B.; Bartoli, F.; Carrà, G.; Stańczykiewicz, B.; Gładka, A.; Frydecka, D.; Samochowiec, J.; Jarosz, K.; Hadryś, T.; Miller, B.J. Immune-inflammatory markers and psychosis risk: A systematic review and meta-analysis. Psychoneuroendocrinology 2021, 127, 105200. [CrossRef]

40. Liu, J.Y.; Chen, H.Y.; Lin, J.J.; Lu, M.K.; Tan, H.P.; Jang, F.L.; Lin, S.H. Alterations of plasma cytokine biomarkers for identifying age at onset of schizophrenia with neurological soft signs. Int. J. Med. Sci. 2020, 17, 255-262. [CrossRef]

41. Wang, A.K.; Miller, B.J. Meta-analysis of Cerebrospinal Fluid Cytokine and Tryptophan Catabolite Alterations in Psychiatric Patients: Comparisons between Schizophrenia, Bipolar Disorder, and Depression. Schizophr. Bull. 2018, 44, 75-83. [CrossRef] [PubMed]

42. Gallego, J.A.; Blanco, E.A.; Husain-Krautter, S.; Madeline Fagen, E.; Moreno-Merino, P.; del Ojo-Jiménez, J.A.; Ahmed, A.; Rothstein, T.L.; Lencz, T.; Malhotra, A.K. Cytokines in cerebrospinal fluid of patients with schizophrenia spectrum disorders: New data and an updated meta-analysis. Schizophr. Res. 2018, 202, 64-71. [CrossRef]

43. Orlovska-waast, S.; Köhler-forsberg, O.; Wiben, S.; Merete, B.; Kondziella, D.; Krogh, J.; Eriksen, M. Cerebrospinal fl uid markers of in flammation and infections in schizophrenia and affective disorders: A systematic review and meta-analysis. Mol. Psychiatry 2019, 24, 869-887. [CrossRef]

44. Zhou, Y.; Peng, W.; Wang, J.; Zhou, W.J.; Zhou, Y.H.; Ying, B.W. Plasma levels of IL-1Ra are associated with schizophrenia. Psychiatry Clin. Neurosci. 2019, 73, 109-115. [CrossRef]

45. Momtazmanesh, S.; Zare-Shahabadi, A.; Rezaei, N. Cytokine Alterations in Schizophrenia: An Updated Review. Front. Psychiatry 2019, 10, 1-12. [CrossRef] [PubMed] 
46. Dahan, S.; Bragazzi, N.L.; Yogev, A.; Bar-Gad, M.; Barak, V.; Amital, H.; Amital, D. The relationship between serum cytokine levels and degree of psychosis in patients with schizophrenia. Psychiatry Res. 2018, 268, 467-472. [CrossRef]

47. Mao, L.; Zhang, Q.; Li, N.; Wang, F.; Xiang, H.; Zhang, Z.; Su, Y.; Huang, Y.; Zhao, G.; Zhou, R.; et al. Plasma levels of Th17-related cytokines and complement C3 correlated with aggressive behavior in patients with schizophrenia. Psychiatry Res. 2016, 246, 700-706. [CrossRef]

48. Romeo, B.; Brunet-Lecomte, M.; Martelli, C.; Benyamina, A. Kinetics of cytokine levels during antipsychotic treatment in schizophrenia: A meta-Analysis. Int. J. Neuropsychopharmacol. 2018, 21, 828-836. [CrossRef]

49. Tourjman, V.; Kouassi, É.; Koué, M.; Rocchetti, M.; Fortin-Fournier, S.; Fusar-Poli, P.; Potvin, S. Antipsychotics' effects on blood levels of cytokines in schizophrenia: A meta-analysis. Schizophr. Res. 2013, 151, 43-47. [CrossRef] [PubMed]

50. Capuzzi, E.; Bartoli, F.; Crocamo, C.; Clerici, M.; Carrà, G. Acute variations of cytokine levels after antipsychotic treatment in drug-naïve subjects with a first-episode psychosis: A meta-analysis. Neurosci. Biobehav. Rev. 2017, 77, 122-128. [CrossRef] [PubMed]

51. Marcinowicz, P.; Więdłocha, M.; Zborowska, N.; Dębowska, W.; Podwalski, P.; Misiak, B.; Tyburski, E.; Szulc, A. A Meta-Analysis of the Influence of Antipsychotics on Cytokines Levels in First Episode Psychosis. J. Clin. Med. 2021, 10, 2488. [CrossRef]

52. Feng, Z.; Zhang, Y.; You, X.; Zhang, W.; Ma, Y.; Long, Q.; Liu, Z.; Hao, W.; Zeng, Y.; Teng, Z. Effects of risperidone on blood levels of interleukin-6 in schizophrenia. Medicine 2020, 99, e19694. [CrossRef] [PubMed]

53. Brown, A.S.; Hooton, J.; Schaefer, C.A.; Zhang, H.; Petkova, E.; Babulas, V.; Perrin, M.; Gorman, J.M.; Susser, E.S. Elevated Maternal Interleukin-8 Levels and Risk of Schizophrenia in Adult Offspring. Am. J. Psychiatry 2004, 161, 889-895. [CrossRef] [PubMed]

54. Frydecka, D.; Krzystek-Korpacka, M.; Lubeiro, A.; Stramecki, F.; Stańczykiewicz, B.; Beszłej, J.A.; Piotrowski, P.; Kotowicz, K.; Szewczuk-Bogusławska, M.; Pawlak-Adamska, E.; et al. Profiling inflammatory signatures of schizophrenia: A cross-sectional and meta-analysis study. Brain. Behav. Immun. 2018, 71, 28-36. [CrossRef]

55. Ouyang, W.; O'Garra, A. IL-10 Family Cytokines IL-10 and IL-22: From Basic Science to Clinical Translation. Immunity 2019, 50, 871-891. [CrossRef] [PubMed]

56. Álvarez-Satta, M.; Berna-Erro, A.; Carrasco-Garcia, E.; Alberro, A.; Saenz-Antoñanzas, A.; Vergara, I.; Otaegui, D.; Matheu, A. Relevance of oxidative stress and inflammation in frailty based on human studies and mouse models. Aging 2020, 12, 9982-9999. [CrossRef] [PubMed]

57. Kaplanski, G. Interleukin-18: Biological properties and role in disease pathogenesis. Immunol. Rev. 2018, 281, 138-153. [CrossRef] [PubMed]

58. Fraguas, D.; Díaz-Caneja, C.M.; Rodríguez-Quiroga, A.; Arango, C. Oxidative Stress and Inflammation in Early Onset First Episode Psychosis: A Systematic Review and Meta-Analysis. Int. J. Neuropsychopharmacol. 2017, 20, 435-444. [CrossRef]

59. Wedervang-Resell, K.; Friis, S.; Lonning, V.; Smelror, R.E.; Johannessen, C.; Reponen, E.J.; Lyngstad, S.H.; Lekva, T.; Aukrust, P.; Ueland, T.; et al. Increased interleukin 18 activity in adolescents with early-onset psychosis is associated with cortisol and depressive symptoms. Psychoneuroendocrinology 2020, 112, 104513. [CrossRef]

60. Luo, Y.; He, H.; Zhang, J.; Ou, Y.; Fan, N. Changes in serum TNF- $\alpha$, IL-18, and IL-6 concentrations in patients with chronic schizophrenia at admission and at discharge. Compr. Psychiatry 2019, 90, 82-87. [CrossRef]

61. Probert, L. TNF and its receptors in the CNS: The essential, the desirable and the deleterious effects. Neuroscience 2015, $302,2-22$. [CrossRef]

62. Bianconi, V.; Sahebkar, A.; Atkin, S.L.; Pirro, M. The Regulation and Importance of Monocyte Chemoattractant Protein-1. Curr. Opin. Hematol. 2018, 25, 44-51. [CrossRef]

63. Ganju, R.K.; Brubaker, S.A.; Chernock, R.D.; Avraham, S.; Groopman, J.E. $\beta$-Chemokine Receptor CCR5 Signals through SHP1, SHP2, and Syk. J. Biol. Chem. 2000, 275, 17263-17268. [CrossRef] [PubMed]

64. Tatara, Y.; Ohishi, M.; Yamamoto, K.; Shiota, A.; Hayashi, N.; Iwamoto, Y.; Takeda, M.; Takagi, T.; Katsuya, T.; Ogihara, T.; et al. Macrophage Inflammatory Protein-1 $\beta$ Induced Cell Adhesion with Increased Intracellular Reactive Oxygen Species. J. Mol. Cell. Cardiol. 2009, 47, 104-111. [CrossRef] [PubMed]

65. Kitaura, M.; Nakajima, T.; Imai, T.; Harada, S.; Combadiere, C.; Tiffany, H.L.; Murphy, P.M.; Yoshie, O. Molecular Cloning of Human Eotaxin, an Eosinophil-Selective CC Chemokine, and Identification of a Specific Eosinophil Eotaxin Receptor, CC Chemokine Receptor 3. J. Biol. Chem. 1996, 271, 7725-7730. [CrossRef] [PubMed]

66. Teixeira, A.L.; Gama, C.S.; Rocha, N.P.; Teixeira, M.M. Revisiting the Role of Eotaxin-1/CCL11 in Psychiatric Disorders. Front. Psychiatry 2018, 9, 1-6. [CrossRef]

67. Pouget, J.G. The emerging immunogenetic architecture of schizophrenia. Schizophr. Bull. 2018, 44, 993-1004. [CrossRef]

68. Butler, M.G.; McGuire, A.B.; Masoud, H.; Manzardo, A.M. Currently recognized genes for schizophrenia: High-resolution chromosome ideogram representation. Am. J. Med. Genet. Part B Neuropsychiatr. Genet. 2016, 171, 181-202. [CrossRef]

69. Frydecka, D.; Misiak, B.; Pawlak-Adamska, E.; Karabon, L.; Tomkiewicz, A.; Sedlaczek, P.; Kiejna, A.; Beszłej, J.A. Interleukin-6: The missing element of the neurocognitive deterioration in schizophrenia? The focus on genetic underpinnings, cognitive impairment and clinical manifestation. Eur. Arch. Psychiatry Clin. Neurosci. 2015, 265, 449-459. [CrossRef]

70. Sanders, A.R.; Drigalenko, E.I.; Duan, J.; Moy, W.; Freda, J.; Göring, H.H.H.; Gejman, P.V.; Levinson, D.F.; Shi, J.; Buccola, N.G.; et al. Transcriptome sequencing study implicates immune-related genes differentially expressed in schizophrenia: New data and a meta-analysis. Transl. Psychiatry 2017, 7, 1-10. [CrossRef] 
71. Mak, M.; Misiak, B.; Frydecka, D.; Pełka-Wysiecka, J.; Kucharska-Mazur, J.; Samochowiec, A.; Bieńkowski, P.; Pawlak-Adamska, E.; Karabon, L.; Szmida, E.; et al. Polymorphisms in immune-inflammatory response genes and the risk of deficit schizophrenia. Schizophr. Res. 2018, 193, 359-363. [CrossRef] [PubMed]

72. Suchanek-Raif, R.; Raif, P.; Kowalczyk, M.; Paul-Samojedny, M.; Kucia, K.; Merk, W.; Kowalski, J. Polymorphic Variants of TNFR2 Gene in Schizophrenia and Its Interaction with -308G/A TNF- $\alpha$ Gene Polymorphism. Mediators Inflamm. 2018, 2018, 1-6. [CrossRef] [PubMed]

73. Hartwell, K.J.; Maria, M.M.M.; Twal, W.O.; Shaftman, S.; Desantis, S.M.; Mcrae-clark, A.L.; Pharm, D.; Brady, K.T. Association of Elevated Cytokines with Childhood Adversity in a Sample of Healthy Adults. J. Psychiatr. Res. 2013, 47, 604-610. [CrossRef] [PubMed]

74. Hostinar, C.E.; Davidson, R.J.; Graham, E.K.; Mroczek, D.K.; Lachman, M.E.; Seeman, T.E.; van Reekum, C.M.; Miller, G.E. Frontal brain asymmetry, childhood maltreatment, and low-grade inflammation at midlife. Psychoneuroendocrinology 2017, 75, 152-163. [CrossRef]

75. Renna, M.E.; Peng, J.; Shrout, M.R.; Madison, A.A.; Andridge, R.; Alfano, C.M.; Povoski, S.P.; Lipari, A.M.; Malarkey, W.B.; Kiecolt-Glaser, J.K. Childhood abuse histories predict steeper inflammatory trajectories across time. Brain. Behav. Immun. 2021, 91, 541-545. [CrossRef]

76. Holland, J.F.; Khandaker, G.M.; Dauvermann, M.R.; Morris, D.; Zammit, S.; Donohoe, G. Effects of early life adversity on immune function and cognitive performance: Results from the ALSPAC cohort. Soc. Psychiatry Psychiatr. Epidemiol. 2020, 55, 723-733. [CrossRef]

77. Baumeister, D.; Akhtar, R.; Ciufolini, S.; Pariante, C.M.; Mondelli, V. Childhood trauma and adulthood inflammation: A meta-analysis of peripheral C-reactive protein, interleukin-6 and tumour necrosis factor- $\alpha$. Mol. Psychiatry 2016, 21, 642-649. [CrossRef]

78. Lacey, R.E.; Bartley, M.; Kelly-Irving, M.; Bevilacqua, L.; Iob, E.; Kelly, Y.; Howe, L.D. Adverse childhood experiences and early life inflammation in the Avon longitudinal study of parents and children. Psychoneuroendocrinology 2020, 122, 104914. [CrossRef]

79. Nguyen, J.K.; Thurston, R.C. Association of Childhood Trauma Exposure with Inflammatory Biomarkers among Midlife Women. J. Women's Health 2020, 29, 1540-1546. [CrossRef]

80. Dennison, U.; McKernan, D.; Cryan, J.; Dinan, T. Schizophrenia patients with a history of childhood trauma have a proinflammatory phenotype. Psychol. Med. 2012, 42, 1865-1871. [CrossRef]

81. Di Nicola, M.; Cattaneo, A.; Hepgul, N.; Di Forti, M.; Aitchison, K.J.; Janiri, L.; Murray, R.M.; Dazzan, P.; Pariante, C.M.; Mondelli, V. Serum and gene expression profile of cytokines in first-episode psychosis. Brain. Behav. Immun. 2013, 31, 90-95. [CrossRef]

82. Chase, K.A.; Melbourne, J.K.; Rosen, C.; McCarthy-Jones, S.; Jones, N.; Feiner, B.M.; Sharma, R.P. Traumagenics: At the intersect of childhood trauma, immunity and psychosis. Psychiatry Res. 2019, 273, 369-377. [CrossRef]

83. Corsi-Zuelli, F.; Loureiro, C.M.; Shuhama, R.; Fachim, H.A.; Menezes, P.R.; Louzada-Junior, P.; Mondelli, V.; Del-Ben, C.M. Cytokine profile in first-episode psychosis, unaffected siblings and community-based controls: The effects of familial liability and childhood maltreatment. Psychol. Med. 2020, 50, 1139-1147. [CrossRef]

84. Quidé, Y.; Bortolasci, C.C.; Spolding, B.; Kidnapillai, S.; Watkeys, O.J.; Cohen-Woods, S.; Carr, V.J.; Berk, M.; Walder, K.; Green, M.J. Systemic inflammation and grey matter volume in schizophrenia and bipolar disorder: Moderation by childhood trauma severity. Prog. Neuro-Psychopharmacol. Biol. Psychiatry 2021, 105, 110013. [CrossRef]

85. Collins, S.M.; Kassam, Z.; Bercik, P. The adoptive transfer of behavioral phenotype via the intestinal microbiota: Experimental evidence and clinical implications. Curr. Opin. Microbiol. 2013, 16, 240-245. [CrossRef] [PubMed]

86. Erny, D.; Hrabě de Angelis, A.L.; Jaitin, D.; Wieghofer, P.; Staszewski, O.; David, E.; Keren-Shaul, H.; Mahlakoiv, T.; Jakobshagen, K.; Buch, T.; et al. Host microbiota constantly control maturation and function of microglia in the CNS. Nat. Neurosci. 2015, 18, 965-977. [CrossRef] [PubMed]

87. Rothhammer, V.; Mascanfroni, I.D.; Bunse, L.; Takenaka, M.C.; Kenison, J.E.; Mayo, L.; Chao, C.-C.; Patel, B.; Yan, R.; Blain, M.; et al. Type I interferons and microbial metabolites of tryptophan modulate astrocyte activity and central nervous system inflammation via the aryl hydrocarbon receptor. Nat. Med. 2016, 22, 586-597. [CrossRef] [PubMed]

88. Liu, R.T. The microbiome as a novel paradigm in studying stress and mental health. Am. Psychol. 2017, 72, 655-667. [CrossRef]

89. Santos, J.; Yang, P.C.; Söderholm, J.D.; Benjamin, M.; Perdue, M.H. Role of mast cells in chronic stress induced colonic epithelial barrier dysfunction in the rat. Gut 2001, 48, 630-636. [CrossRef]

90. Vogel, S.C.; Brito, N.H.; Callaghan, B.L. Early Life Stress and the Development of the Infant Gut Microbiota: Implications for Mental Health and Neurocognitive Development. Curr. Psychiatry Rep. 2020, 22, 61. [CrossRef]

91. Alexandrov, P.N.; Zhao, Y.; Li, W.; Lukiw, W.J. Lipopolysaccharide-stimulated, NF-kB-, miRNA-146a- And miRNA-155-mediated molecular-genetic communication between the human gastrointestinal tract microbiome and the brain. Folia Neuropathol. 2019, 57, 211-219. [CrossRef] [PubMed]

92. Castro-Nallar, E.; Bendall, M.L.; Pérez-Losada, M.; Sabuncyan, S.; Severance, E.G.; Dickerson, F.B.; Schroeder, J.R.; Yolken, R.H.; Crandall, K.A. Composition, taxonomy and functional diversity of the oropharynx microbiome in individuals with schizophrenia and controls. Peer] 2015, 2015, 1-21. [CrossRef]

93. Schwarz, E.; Maukonen, J.; Hyytiäinen, T.; Kieseppä, T.; Orešič, M.; Sabunciyan, S.; Mantere, O.; Saarela, M.; Yolken, R.; Suvisaari, J. Analysis of microbiota in first episode psychosis identifies preliminary associations with symptom severity and treatment response. Schizophr. Res. 2018, 192, 398-403. [CrossRef] 
94. Pełka-Wysiecka, J.; Kaczmarczyk, M.; Bąba-Kubiś, A.; Liśkiewicz, P.; Wroński, M.; Skonieczna-Żydecka, K.; Marlicz, W.; Misiak, B.; Starzyńska, T.; Kucharska-Mazur, J.; et al. Analysis of Gut Microbiota and Their Metabolic Potential in Patients with Schizophrenia Treated with Olanzapine: Results from a Six-Week Observational Prospective Cohort Study. J. Clin. Med. 2019, 8, 1605. [CrossRef]

95. Nguyen, T.T.; Kosciolek, T.; Eyler, L.T.; Knight, R.; Jeste, D.V. Overview and systematic review of studies of microbiome in schizophrenia and bipolar disorder. J. Psychiatr. Res. 2018, 99, 50-61. [CrossRef] [PubMed]

96. Galderisi, S.; Delisi, L.E.; Borgwardt, S. Neuroimaging of Schizophrenia and Other Primary Psychotic Disorders; Springer International Publishing: Cham, Switzerland, 2019; ISBN 9783319973067.

97. Steen, R.G.; Mull, C.; McClure, R.; Hamer, R.M.; Lieberman, J.A. Brain volume in first-episode schizophrenia: Systematic review and meta-analysis of magnetic resonance imaging studies. Br. J. Psychiatry 2006, 188, 510-518. [CrossRef] [PubMed]

98. Kelly, S.; Jahanshad, N.; Zalesky, A.; Kochunov, P.; Agartz, I.; Alloza, C.; Andreassen, O.A.; Arango, C.; Banaj, N.; Bouix, S.; et al. Widespread white matter microstructural differences in schizophrenia across 4322 individuals: Results from the ENIGMA Schizophrenia DTI Working Group. Mol. Psychiatry 2018, 23, 1261-1269. [CrossRef]

99. Najjar, S.; Pearlman, D.M.; Alper, K.; Najjar, A.; Devinsky, O. Neuroinflammation and psychiatric illness. J. Neuroinflamm. 2013, 10, 1-24. [CrossRef] [PubMed]

100. Wu, D.; Lv, P.; Li, F.; Zhang, W.; Fu, G.; Dai, J.; Hu, N.; Liu, J.; Xiao, Y.; Li, S.; et al. Association of peripheral cytokine levels with cerebral structural abnormalities in schizophrenia. Brain Res. 2019, 1724, 146463. [CrossRef] [PubMed]

101. Fillman, S.G.; Weickert, T.W.; Lenroot, R.K.; Catts, S.V.; Bruggemann, J.M.; Catts, V.S.; Weickert, C.S. Elevated peripheral cytokines characterize a subgroup of people with schizophrenia displaying poor verbal fluency and reduced Broca's area volume. Mol. Psychiatry 2016, 21, 1090-1098. [CrossRef]

102. Hoseth, E.Z.; Westlye, L.T.; Hope, S.; Dieset, I.; Aukrust, P.; Melle, I.; Haukvik, U.K.; Agartz, I.; Ueland, T.; Ueland, T.; et al. Association between cytokine levels, verbal memory and hippocampus volume in psychotic disorders and healthy controls. Acta Psychiatr. Scand. 2016, 133, 53-62. [CrossRef]

103. Ellman, L.M.; Deicken, R.F.; Vinogradov, S.; Kremen, W.S.; Poole, J.H.; Kern, D.M.; Tsai, W.Y.; Schaefer, C.A.; Brown, A.S. Structural brain alterations in schizophrenia following fetal exposure to the inflammatory cytokine interleukin-8. Schizophr. Res. 2010, 121, 46-54. [CrossRef]

104. Chew, L.J.; Fusar-Poli, P.; Schmitz, T. Oligodendroglial alterations and the role of microglia in white matter injury: Relevance to schizophrenia. Dev. Neurosci. 2013, 35, 102-129. [CrossRef]

105. Podwalski, P.; Szczygieł, K.; Tyburski, E.; Sagan, L.; Misiak, B.; Samochowiec, J. Magnetic resonance diffusion tensor imaging in psychiatry: A narrative review of its potential role in diagnosis. Pharmacol. Rep. 2021, 73, 43-56. [CrossRef] [PubMed]

106. Prasad, K.M.; Upton, C.H.; Nimgaonkar, V.L.; Keshavan, M.S. Differential susceptibility of white matter tracts to inflammatory mediators in schizophrenia: An integrated DTI study. Schizophr. Res. 2015, 161, 119-125. [CrossRef] [PubMed]

107. Di Biase, M.A.; Zalesky, A.; Cetin-Karayumak, S.; Rathi, Y.; Lv, J.; Boerrigter, D.; North, H.; Tooney, P.; Pantelis, C.; Pasternak, O.; et al. Large-Scale Evidence for an Association between Peripheral Inflammation and White Matter Free Water in Schizophrenia and Healthy Individuals. Schizophr. Bull. 2021, 47, 542-551. [CrossRef] [PubMed]

108. Dietz, A.G.; Goldman, S.A.; Nedergaard, M. Glial Cells in Schizophrenia: A Unified Hypothesis. Lancet Psychiatry 2020, 7, $272-281$. [CrossRef]

109. Trépanier, M.O.; Hopperton, K.E.; Mizrahi, R.; Mechawar, N.; Bazinet, R.P. Postmortem Evidence of Cerebral Inflammation in Schizophrenia: A Systematic Review. Mol. Psychiatry 2016, 21, 1009-1026. [CrossRef]

110. Marques, T.R.; Ashok, A.H.; Pillinger, T.; Veronese, M.; Turkheimer, F.E.; Dazzan, P.; Sommer, I.E.C.; Howes, O.D. Neuroinflammation in Schizophrenia: Meta-Analysis of in Vivo Microglial Imaging Studies. Psychol. Med. 2019, 49, 2186-2196. [CrossRef]

111. Bobbo, V.C.D.; Jara, C.P.; Mendes, N.F.; Morari, J.; Velloso, L.A.; Araújo, E.P. Interleukin-6 Expression by Hypothalamic Microglia in Multiple Inflammatory Contexts: A Systematic Review. BioMed Res. Int. 2019, 2019, 1-11. [CrossRef] [PubMed]

112. Spittau, B.; Dokalis, N.; Prinz, M. The Role of TGF $\beta$ Signaling in Microglia Maturation and Activation. Trends Immunol. 2020, 41, 836-848. [CrossRef] [PubMed]

113. Plitman, E.; Iwata, Y.; Caravaggio, F.; Nakajima, S.; Chung, J.K.; Gerretsen, P.; Kim, J.; Takeuchi, H.; Chakravarty, M.M.; Remington, G.; et al. Kynurenic Acid in Schizophrenia: A Systematic Review and Meta-Analysis. Schizophr. Bull. 2017, 43, 764-777. [CrossRef] [PubMed]

114. Badawy, A.A.B. Kynurenine Pathway of Tryptophan Metabolism: Regulatory and Functional Aspects. Int. J. Tryptophan Res. 2017, 10, 1178646917691938. [CrossRef] [PubMed]

115. Kindler, J.; Lim, C.K.; Weickert, C.S.; Boerrigter, D.; Galletly, C.; Liu, D.; Jacobs, K.R.; Balzan, R.; Bruggemann, J.; O’Donnell, M.; et al. Dysregulation of Kynurenine Metabolism Is Related to Proinflammatory Cytokines, Attention, and Prefrontal Cortex Volume in Schizophrenia. Mol. Psychiatry 2019, 25, 2860-2872. [CrossRef]

116. Mei, Y.Y.; Wu, D.C.; Zhou, N. Astrocytic Regulation of Glutamate Transmission in Schizophrenia. Front. Psychiatry 2018, 9, 1-10. [CrossRef]

117. Schwartz, T.L.; Sachdeva, S.; Stahl, S.M. Glutamate Neurocircuitry: Theoretical Underpinnings in: Schizophrenia. Front. Pharmacol. 2012, 3, 1-11. [CrossRef]

118. Akkouh, I.A.; Ueland, T.; Hansson, L.; Inderhaug, E.; Hughes, T.; Steen, N.E.; Aukrust, P.; Andreassen, O.A.; Szabo, A.; Djurovic, S. Decreased IL-1 $\beta$-Induced CCL20 Response in Human IPSC-Astrocytes in Schizophrenia: Potential Attenuating Effects on Recruitment of Regulatory T Cells. Brain Behav. Immun. 2020, 87, 634-644. [CrossRef] 
119. Herman, F.J.; Pasinetti, G.M. Principles of Inflammasome Priming and Inhibition: Implications for Psychiatric Disorders. Brain Behav. Immun. 2018, 73, 66-84. [CrossRef] [PubMed]

120. Volk, D.W.; Moroco, A.E.; Roman, K.M.; Edelson, J.R.; Lewis, D.A. The Role of the Nuclear Factor-KB Transcriptional Complex in Cortical Immune Activation in Schizophrenia. Biol. Psychiatry 2019, 85, 25-34. [CrossRef] [PubMed]

121. Volk, D.W.; Chitrapu, A.; Edelson, J.R.; Roman, K.M.; Moroco, A.E.; Lewis, D.A. Molecular Mechanisms and Timing of Cortical Immune Activation in Schizophrenia. Am. J. Psychiatry 2015, 172, 1112-1121. [CrossRef]

122. Hubbard, D.B.; Miller, B.J. Meta-Analysis of Blood Cortisol Levels in Individuals with First-Episode Psychosis. Psychoneuroendocrinology 2019, 104, 269-275. [CrossRef]

123. Misiak, B.; Łoniewski, I.; Marlicz, W.; Frydecka, D.; Szulc, A.; Rudzki, L.; Samochowiec, J. The HPA Axis Dysregulation in Severe Mental Illness: Can We Shift the Blame to Gut Microbiota? Prog. Neuro-Psychopharmacol. Biol. Psychiatry 2020, $102,109951$. [CrossRef] [PubMed]

124. Jiang, S.; Postovit, L.; Cattaneo, A.; Binder, E.B.; Aitchison, K.J. Epigenetic Modifications in Stress Response Genes Associated With Childhood Trauma. Front. Psychiatry 2019, 10, 1-19. [CrossRef] [PubMed]

125. Gruchot, J.; Kremer, D.; Küry, P. Neural Cell Responses upon Exposure to Human Endogenous Retroviruses. Front. Genet. 2019, 10, 1-7. [CrossRef] [PubMed]

126. Brudek, T.; Lühdorf, P.; Christensen, T.; Hansen, H.J.; Møller-Larsen, A. Activation of Endogenous Retrovirus Reverse Transcriptase in Multiple Sclerosis Patient Lymphocytes by Inactivated HSV-1, HHV-6 and VZV. J. Neuroimmunol. 2007, 187, 147-155. [CrossRef] [PubMed]

127. Mameli, G.; Madeddu, G.; Mei, A.; Uleri, E.; Poddighe, L.; Delogu, L.G.; Maida, I.; Babudieri, S.; Serra, C.; Manetti, R.; et al. Activation of MSRV-Type Endogenous Retroviruses during Infectious Mononucleosis and Epstein-Barr Virus Latency: The Missing Link with Multiple Sclerosis? PLOS ONE 2013, 8, e78474. [CrossRef]

128. Khandaker, G.M.; Zimbron, J.; Lewis, G.; Jones, P.B. Prenatal Maternal Infection, Neurodevelopment and Adult Schizophrenia: A Systematic Review of Population-Based Studies. Psychol. Med. 2013, 43, 239-257. [CrossRef]

129. Dickerson, F.; Schroeder, J.R.; Nimgaonkar, V.; Gold, J.; Yolken, R. The Association between Exposure to Herpes Simplex Virus Type 1 (HSV-1) and Cognitive Functioning in Schizophrenia: A Meta-Analysis. Psychiatry Res. 2020, 291, 113157. [CrossRef]

130. Mameli, G.; Astone, V.; Khalili, K.; Serra, C.; Sawaya, B.E.; Dolei, A. Regulation of the Syncytin-1 Promoter in Human Astrocytes by Multiple Sclerosis-Related Cytokines. Virology 2007, 362, 120-130. [CrossRef]

131. Manghera, M.; Ferguson-Parry, J.; Lin, R.; Douville, R.N. NF-KB and IRF1 Induce Endogenous Retrovirus K Expression via Interferon-Stimulated Response Elements in Its 5' Long Terminal Repeat. J. Virol. 2016, 90, 9338-9349. [CrossRef]

132. Hurst, T.P.; Magiorkinis, G. Epigenetic Control of Human Endogenous Retrovirus Expression: Focus on Regulation of LongTerminal Repeats (LTRs). Viruses 2017, 9, 130. [CrossRef]

133. Xiao, R.; Li, S.; Cao, Q.; Wang, X.; Yan, Q.; Tu, X.; Zhu, Y.; Zhu, F. Human Endogenous Retrovirus W Env Increases Nitric Oxide Production and Enhances the Migration Ability of Microglia by Regulating the Expression of Inducible Nitric Oxide Synthase. Virol. Sin. 2017, 32, 216-225. [CrossRef]

134. Wang, X.; Wu, X.; Huang, J.; Li, H.; Yan, Q.; Zhu, F. Human Endogenous Retrovirus W Family Envelope Protein (HERV-W Env) Facilitates the Production of TNF- $\alpha$ and IL-10 by Inhibiting MyD88s in Glial Cells. Arch. Virol. 2021, 166, 1035-1045. [CrossRef] [PubMed]

135. Deguine, J.; Barton, G.M. MyD88: A Central Player in Innate Immune Signaling. F1000Prime Rep. 2014, 6, 1-7. [CrossRef]

136. Janssens, S.; Burns, K.; Vercammen, E.; Tschopp, J.; Beyaert, R. MyD88S, a Splice Variant of MyD88, Differentially Modulates NF-KB- and AP-1-Dependent Gene Expression. FEBS Lett. 2003, 548, 103-107. [CrossRef]

137. Karlsson, H.; Bachmann, S.; Schröder, J.; McArthur, J.; Torrey, E.F.; Yolken, R.H. Retroviral RNA Identified in the Cerebrospinal Fluids and Brains of Individuals with Schizophrenia. Proc. Natl. Acad. Sci. USA 2001, 98, 4634-4639. [CrossRef] [PubMed]

138. Frank, O.; Giehl, M.; Zheng, C.; Hehlmann, R.; Leib-Mösch, C.; Seifarth, W. Human Endogenous Retrovirus Expression Profiles in Samples from Brains of Patients with Schizophrenia and Bipolar Disorders. J. Virol. 2005, 79, 10890-10901. [CrossRef]

139. Mak, M.; Samochowiec, J.; Frydecka, D.; Pełka-Wysiecka, J.; Szmida, E.; Karpiński, P.; Sąsiadek, M.M.; Piotrowski, P.; Samochowiec, A.; Misiak, B. First-Episode Schizophrenia Is Associated with a Reduction of HERV-K Methylation in Peripheral Blood. Psychiatry Res. 2019, 271, 459-463. [CrossRef]

140. Suntsova, M.; Gogvadze, E.V.; Salozhin, S.; Gaifullin, N.; Eroshkin, F.; Dmitriev, S.E.; Martynova, N.; Kulikov, K.; Malakhova, G.; Tukhbatova, G.; et al. Human-Specific Endogenous Retroviral Insert Serves as an Enhancer for the Schizophrenia-Linked Gene PRODH. Proc. Natl. Acad. Sci. USA 2013, 110, 19472-19477. [CrossRef] [PubMed]

141. Huang, W.; Li, S.; Hu, Y.; Yu, H.; Luo, F.; Zhang, Q.; Zhu, F. Implication of the Env Gene of the Human Endogenous Retrovirus W Family in the Expression of BDNF and DRD3 and Development of Recent-Onset Schizophrenia. Schizophr. Bull. 2011, 37, 988-1000. [CrossRef]

142. Tamouza, R.; Meyer, U.; Foiselle, M.; Richard, J.R.; Lu, C.; Boukouaci, W.; le Corvoisier, P.; Barrau, C.; Lucas, A.; Perron, H.; et al. Identification of Inflammatory Subgroups of Schizophrenia and Bipolar Disorder Patients with HERV-W ENV Antigenemia by Unsupervised Cluster Analysis. Transl. Psychiatry 2021, 11, 1-8. [CrossRef] [PubMed]

143. Martinuzzi, E.; Barbosa, S.; Daoudlarian, D.; Bel Haj Ali, W.; Gilet, C.; Fillatre, L.; Khalfallah, O.; Troudet, R.; Jamain, S.; Fond, G.; et al. Stratification and prediction of remission in first-episode psychosis patients: The OPTiMiSE cohort study. Transl. Psychiatry 2019, 9, 20. [CrossRef] 
144. Carpenter, T.; Wagman, A.M.I.; Heinrichs, W.; Ph, D. Deficit and Nondeficit form of Schizophrenia: The Concept. Am. J. Psychiatry 1988, 145, 578-583. [PubMed]

145. Kirkpatrick, B.; Galderisi, S. Deficit schizophrenia: An update. World Psychiatry 2008, 7, 143-147. [CrossRef] [PubMed]

146. Köşger, F.; Yiğitaslan, S.; Eşsizoğlu, A.; Güleç, G.; Dağ Karataş, R.; Değirmenci, S. Inflammation and oxidative stress in deficit schizophrenia. Noropsikiyatri Ars. 2020, 57, 303-307. [CrossRef]

147. Garcia-Rizo, C.; Fernandez-Egea, E.; Oliveira, C.; Justicia, A.; Bernardo, M.; Kirkpatrick, B. Inflammatory markers in antipsychoticnaïve patients with nonaffective psychosis and deficit vs. nondeficit features. Psychiatry Res. 2012, 198, 212-215. [CrossRef]

148. Goldsmith, D.; Haroon, E.; Miller, A.; Addington, J.; Bearden, C.; Cadenhead, K.; Cannon, T.; Cornblatt, B.; Mathalon, D.; McGlashan, T.; et al. Association of baseline inflammatory markers and the development of negative symptoms in individuals at clinical high risk for psychosis. Brain. Behav. Immun. 2019, 76, 268-274. [CrossRef] [PubMed]

149. Chen, Y.; Cinnamon Bidwell, L.; Norton, D. Trait vs. State Markers for Schizophrenia: Identification and Characterization Through Visual Processes. Curr. Psychiatry Rev. 2006, 2, 431-438. [CrossRef]

150. Insel, T.; Cuthbert, B.; Garvey, M.; Heinssen, R.; Pine, D.; Quinn, K.; Sanislow, C.; Wang, P. Research Domain Criteria (RDoC): Toward a new classification framework for research on mental disorders. Am. J. Psychiatry Online 2010, 167, 748-751. [CrossRef]

151. Morris, S.E.; Cuthbert, B.N. Research Domain Criteria: Cognitive Systems, Neural Circuits, and Dimensions of Behavior. Dialogues Clin. Neurosci. 2012, 14, 29-37. [CrossRef]

152. Green, B.N.; Johnson, C.D.; Adams, A. Writing narrative literature reviews for peer-reviewed journals: Secrets of the trade. J. Chiropr. Med. 2006, 5, 101-117. [CrossRef] 